\title{
Property Rights and Sacred Sites: Federal Regulatory Responses to American Indian Religious Claims on Public Land
}

\author{
Marcia Yablon
}

\section{INTRODUCTION}

According to the National Trust for Historic Preservation, the Kw'st'an Sacred Sites at Indian Pass in Imperial County, California, are one of America's eleven most endangered historic places. ' For thousands of years, American Indians from the Quechan tribe have undertaken spiritual pilgrimages to these sites and conducted religious ceremonies known as Keruk, in which they have cremated their dead and assisted in bringing them to the next world. ${ }^{2}$ These sites are on the National Trust's list because, in addition to being rich in spiritual and cultural significance, Indian Pass is also rich in gold. Glamis Gold Ltd., a Canadian mining company, is seeking permission to extract the gold; if granted, such permission will result in "a massive 1,600-acre cyanide heap-leach gold-mine that will leave a gaping hole in the ground and a skyscraper-size mound of toxic waste., ${ }^{3}$

The situation at Indian Pass is not unique. Dozens and potentially hundreds of Indian sacred sites face similar threats. ${ }^{4}$ For those seeking to

1. The National Trust issues an annual list of the eleven most endangered historic places in the United States. The 2002 list included the Kw'st'an Sacred Sites as well as a collection of Indian sacred sites along the Missouri River. Nat'l Trust for Historic Pres., America's 11 Most Endangered Historic Places 2002, at http://www.nationaltrust.org/11Most/2002/sacredsites.html (last visited Jan. 28, 2004) [hereinafter Nat'l Trust for Historic Pres., Endangered Historic Places 2002]. In addition, the 2003 list included the Zuni Salt Lake, discussed in Part III. Nat'l Trust for Historic Pres., America's 11 Most Endangered Historic Places 2003, at http://www.nationaltrust.org/11Most/2003/index.html (last visited Feb. 18, 2004).

2. Nat'l Trust for Historic Pres., Endangered Historic Places 2002, supra note 1.

3. Id.

4. The number of threatened sites has varied over the years. In 1993, the Association on American Indian Affairs identified forty-four sites as threatened by tourism, development, and vandalism. Karen L. Michel, Indians To Ask U.S. To Bolster Law on Religious Freedom, DALLAS MORNING NEWS, Mar. 8, 1993, at 1A. In November 2002, the National Congress of American Indians identified twenty-three sites as facing such threats. Nat'l Cong. of Am. Indians, 
protect such sites, both the problems and the solution are clear. Most sacred sites supporters believe that the Supreme Court's unwillingness to find that the First Amendment mandates the protection of sacred sites has led to this precarious and distressing situation. ${ }^{5}$ They further believe that the only way to ensure the protection of these sites is either to overrule the Court's previous decisions ${ }^{6}$ or to pass a comprehensive statute giving tribes the power to prevent the destruction or development of their sacred sites. ${ }^{7}$ Those holding this view believe that anything less than these types of sweeping measures will be disastrous for the future of Indian sacred sites. Yet as widespread as this belief is, it may not be correct. Furthermore, it may actually be a good thing for society as a whole that these proposed protections have not succeeded.

Indian sacred sites are lands that hold significant spiritual value for an Indian tribe. These sites may be discrete geological monuments such as Bear Lodge (also known as Devils Tower) in Wyoming, a sixty-millionyear-old rock formation made from the hardened magma of an extinct volcano, ${ }^{8}$ or wide swaths of land such as the Indian Pass Sacred Sites, a series of trails running from Los Angeles to Mexico. ${ }^{9}$ Some sites factor into a tribe's creation myth or are vital to the continuing practice of a tribe's

Resolution \#SD-02-018, Protection of Threatened Sacred Places: An Urgent Priority, http://www.ncai.org/data/docs/resolution/2002Annual/018.pdf (last visited Feb. 18, 2004).

5. See, e.g., Samuel D. Brooks, Note, Native American Indians' Fruitless Search for First Amendment Protection of Their Sacred Religious Sites, 24 VAL. U. L. REV. 521, 546 (1990) (stating that "the Court severely narrowed the protection that the first amendment has traditionally given religious practices and incorrectly concluded that there was no burden on any Native American Indian religious practice").

6. Joel Brady, "Land Is Itself a Sacred, Living Being": Native American Sacred Site Protection on Federal Public Land Amidst the Shadows of Bear Lodge, 24 AM. INDIAN L. REV. $153,172-73$ (1999-2000) ("[T]he hope is that Bear Lodge will actually make its way to the Supreme Court and set new precedent [regarding the constitutionality of protecting sacred sites].").

7. For an example of such legislation, see the narrowly defeated California bills S. 1828, 2001-2002 Gen. Assem., Reg. Sess. (Cal. 2002), WL 2001 CA S.B. 1828 (SN), and S. 483, 2001-2002 Gen. Assem., Reg. Sess. (Cal. 2002), WL 2001 CA S.B. 483 (SN), which would have given "Native American tribes in California de facto veto power to strike down public and private development projects throughout the state," Bill Hom, Clash of Cultures, Religions, SAN DIEGO UNION-TRIB., Sept. 12, 2002, at B13. Fifty California tribes supported the bills. James May, Davis Vetoes Sacred Sites Bill, INDIAN COUNTRY TODAY, Oct. 9, 2002, at A1; see also Brady, supra note 6, at 175-78 (discussing the Native American Cultural Protection and Free Exercise of Religion Act of 1994, S. 2269, 103d Cong. (1994), which would have increased protection for Indian sacred sites but failed in the Senate, in large part due to Establishment Clause concerns over its constitutionality); Shawna Lee, Note, Government Managed Shrines: Protection of Native American Sacred Site Worship, 35 VAL. U. L. REV. 265, 304-08 (2000) (discussing the difficulties of drafting constitutional sacred sites protection legislation).

8. Charlton H. Bonham, Devils Tower, Rainbow Bridge and the Uphill Battle Facing Native American Religion on Public Lands, 20 LAW \& INEQ. 157, 174 (2002).

9. A Bill To Protect Sacred Native American Federal Lands: Hearing on H.R. 5155 Before the House Comm. on Res., 107th Cong. 58 (2002) (statement of R. Timothy McCrum, Partner, Crowell \& Moring LLP, on behalf of Glamis Imperial Corp.) [hereinafter Sacred Land Hearings]. 
religion. ${ }^{10}$ For example, for the past 10,000 years, the Lakota have performed their most important religious ceremonies, such as yearly Sun Dances, at Bear Lodge. ${ }^{1}$ Conversely, other sites are used less regularly and for multiple purposes. The Quechan tribe has used Indian Pass for a variety of religious purposes, including Keruk, the ceremony of bringing the dead into the next world; vision quests, where tribal members run in search of visions; and prayer circles. ${ }^{12}$

Just as there are different types of sacred sites, these sites face many different types of threats. For instance, Bear Lodge is a national monument and, as such, is in no danger of being demolished or developed. But for those tribes that believe Bear Lodge is a sacred site, simply having the site open to the public - especially for activities such as rock climbing-is seen as a serious threat.: The threat to Indian Pass is even starker: Parts of it face destruction if developers are given the right to dig up the land and turn it into a leach mine. Although the threats to these sites are serious, the costs of protecting them are just as significant. The difficulty with sacred sites protection is that preventing development and other uses of these lands often has a huge economic impact. For instance, the Glamis gold mine alone may be worth as much as fifty million dollars. ${ }^{13}$

All sacred sites controversies involve the issue of control: Who has the right to control how these sites are used and who gets to use them? The difficulty of the issue is compounded by its magnitude. There are literally tens of thousands of sacred sites. For example, in South Dakota's Black Hills alone, "[t]here are hundreds and estimated thousands of sacred sites." 14 Similarly, the shores of the Missouri River "have hundreds of Indian graves and sacred sites." 15 Furthermore, many of these sites encompass vast expanses of land. Indian Pass is estimated to cover "hundreds of square miles in southern California." much as fifteen miles inland along the entire 1100-mile length of the California coast is also considered a sacred site. ${ }^{17}$ In fact, an expansive

10. Bonham, supra note 8, at 175 .

11.. Id. at $175-76 \&$ n. 137 .

12. Daniel Kraker, Defending the Sacred: Tribes Closer to Meaningful Protection of Religious Sites, AM. INDIAN REP., Nov. 2002, at 12, 14.

13. Courtney Ann Coyle, Defending Quechan Indian Pass-Again, INDIAN COUNTRY TODAY, Nov. 12, 2003, at A4. In addition, the development of these lands also frequently brings much-needed employment opportunities. See infra text accompanying note 206 (discussing the Zuni Salt Lake).

14. David Melmer, Black Hills Defenders Raise Management Issues, INDIAN COUNTRY TODAY, Oct. 1, 2003, at B2.

15. Bill Lambrecht, Boaters Will Face River with Perils Aplenty, ST. LouIS PosT-DiSPATCH, Dec. 15, 2002, at A1.

16. Sacred Land Hearings, supra note 9, at 58 (statement of R. Timothy McCrum, Partner, Crowell \& Moring LLP, on behalf of Glamis Imperial Corp.).

17. James May, Lawmakers Aim To Protect Sacred Sites Along California Coast, INDIAN COUNTRY TODAY, July 16, 2003, at A1. 
definition of sacred sites could encompass a sizeable portion of the undeveloped land in the United States. Accordingly, who decides which sites get protected has enormous ramifications.

Currently, federal land management agencies are responsible for the majority of decisions regarding Indian sacred sites located on federal land. Given that, in the past, land management agencies were often responsible for the decisions to destroy sacred sites, it is little wonder that most tribes and sacred sites supporters are dubious that these agencies will provide any real protection. ${ }^{18}$ But such mistrust may no longer be justified. Land management agencies are increasingly working to protect sacred sites, and in many instances such agencies are able to provide a form of protection that most of society would find preferable to the protections available through the courts or Congress. Unfortunately, many scholars are still so caught up in the perceived lack of broad sacred sites protection that they seem unable to acknowledge that many of these sites are being preserved without any sweeping protections. This Note argues that agency management of Indian sacred sites, in conjunction with statutory consultation provisions and backed by judicial enforcement, is the best form of protection for these sites. In addition, it shows that because of the effectiveness of agency protections, the persistent scholarly arguments for broader judicial or legislative protections are no longer appropriate. This Note also examines the problems with relying on exclusively judicial or legislative protection. It concludes that, because of their greater flexibility, agencies are able to offer a method of sacred sites protection that is better for society as a whole, even if it is less desirable from the viewpoint of individual tribes.

Part I examines the history of Indian sacred sites protection. It discusses the historic lack of agency protection for these sites, the attempt and failure to win judicial protection for them in Lyng v. Northwest Indian Cemetery Protective Ass ' $n,{ }^{19}$ and the impact of Lyng on later sacred sites protection efforts. Part II focuses on recent federal agency efforts to preserve sacred sites, the effectiveness of these efforts, and the reasons behind this change in agency policy. Part III argues that agencies are better able to consider the interests of all users of sacred sites, and therefore that agency protection, when combined with statutory consultation provisions and judicial enforcement, is preferable to the exclusively judicial and legislative protections typically sought by sacred sites advocates. Part III also addresses common criticisms of agency accommodation and explains why

18. See, e.g., George Linge, Ensuring the Full Freedom of Religion on Public Lands: Devils Tower and the Protection of Indian Sacred Sites, 27 B.C. ENVTL. AFF. L. REV. 307, 314 (2000).

19. 485 U.S. 439 (1988). 
agency protection does not leave tribes at the mercy of agency goodwill and changing politics.

\section{THE History OF INDIAN SACREd Sites PROTECTION}

The distrust many sacred sites advocates feel toward land management agencies is warranted. Historically, these agencies have frequently allowed, and even actively encouraged, the development of Indian sacred sites. In 1979, for instance, the U.S. Forest Service approved the development and expansion of the government-owned Snow Bowl ski area on the San Francisco Peaks in the Coconino National Forest of Arizona, despite knowing that the Peaks were sacred to both the Navajo and Hopi tribes. ${ }^{20}$ Similarly, in 1963, the National Park Service built the Glen Canyon Dam in northern Arizona, creating Lake Powell and submerging a sacred Navajo prayer spot. In addition to cutting off access to these now-submerged lands, the formation of the lake dramatically increased the number of visitors to Rainbow Bridge, a geological wonder and an important Indian sacred site. ${ }^{21}$ Before the creation of the lake, few tourists visited the bridge, but after the lake was created, the bridge became a popular tourist destination, adding to the desecration of the site. The increased tourism was actively encouraged by the Park Service, which licensed the operation of tour boats and other tourist activities around the bridge. ${ }^{22}$ In yet another instance of agency involvement in sacred site destruction, the Tennessee Valley Authority-a federal agency created by Congress to provide flood control, navigation, and electric power in the Tennessee Valley region-decided to flood lands along the Little Tennessee River, including burial grounds that were sacred to the Cherokee and integral to their religious practices. ${ }^{23}$

These are just some examples that demonstrate the indifference agencies have often shown in the past toward the protection of sacred sites and Indian culture. ${ }^{24}$ It is this history of indifference that has convinced many scholars and tribal advocates that agencies will never protect Indian sacred sites and that the only way to preserve these lands is through judicial or legislative measures. ${ }^{25}$

20. See Wilson v. Block, 708 F.2d 735, 739 (D.C. Cir. 1983).

21. For factual background, see Badoni v. Higginson, 455 F. Supp. 641, 643 (D. Utah 1977), aff'd, 638 F.2d 172 (10th Cir. 1980).

22. See id.

23. See Sequoyah v. Tenn. Valley Auth., 480 F. Supp. 608, 610 (E.D. Tenn. 1979), aff'd, 620 F.2d 1159 (6th Cir. 1980).

24. For other examples of agencies violating Indian religious practices and destroying sacred sites, see Michael J. Simpson, Accommodating Indian Religions: The Proposed 1993 Amendment to the American Indian Religious Freedom Act, 54 MONT. L. REV. 19, 33 nn.76-77, 34 n.82, 35 nn.87-88 (1993).

25. See Linge, supra note 18 , at 307,314 (bemoaning the fact that the federal government "routinely has acted or has permitted private actions that rendered Indian sacred sites inaccessible 


\section{A. Sacred Sites Litigation Prior to Lyng}

Throughout the 1980s, Indian tribes brought numerous First Amendment suits challenging the constitutionality of developing Indian sacred sites located on federal land. These tribes based their challenges on free exercise grounds, claiming that development on lands they considered sacred would unconstitutionally prevent them from observing religious rituals connected to these sites. ${ }^{26}$ However, even before the Supreme Court's decision in Lyng v. Northwest Indian Cemetery Protective Ass'n, the case most scholars agree ended the possibility of using the First Amendment to protect sacred sites, ${ }^{27}$ free exercise challenges met with little success. Circuit courts hearing these First Amendment cases made it abundantly clear that suits attacking land agency plans for the development of sacred sites would not be viewed favorably. Over and over again, tribes lost these challenges. ${ }^{28}$

In Wilson v. Block, the Hopi and Navajo tribes challenged the aforementioned expansion of the Snow Bowl ski resort on their sacred lands. ${ }^{29}$ The D.C. Circuit rejected their challenge and held that the agency's decision to permit development did not violate the First Amendment because the agency did not deny the tribes access to their sacred sites. ${ }^{30}$ Similarly, in Badoni v. Higginson, in which the Navajo Indians challenged the National Park Service's decision to create Lake Powell and permit tourists to visit Rainbow Bridge, the Tenth Circuit held that the agency's decision did not violate the Free Exercise Clause. ${ }^{31}$ Like the D.C. Circuit, the Badoni court based its opinion in large part on the fact that the Indians in the area still had access to the bridge. ${ }^{32}$ In both cases, continued access was a key factor in the courts' decisions to uphold the development on sacred sites.

However, in Sequoyah v. Tennessee Valley Authority, the case challenging the flooding of burial sites in the Tennessee Valley, even the preservation of tribal access to integral sacred sites was not considered

and unusable for religious ceremonies," and arguing that although "courts scarcely have considered the Indian claims in any but the strictest, most limiting terms," there is "an alternative theory of 'full' religious freedom which would support [sacred sites protection]"); Lee, supra note 7 , at 265 ("Currently, there is no general sacred site protection law. The need for such protection is apparent.... In addition, there is no binding judicial precedent that would offer sacred site protection.").

26. In these cases, tribes typically sought injunctive relief. See, e.g., Sequoyah, 480 F. Supp. at $610 ;$ Badoni, 455 F. Supp. at 643.

27. See infra notes 56-59 and accompanying text.

28. David S. Johnston, Note, The Native American Plight: Protection and Preservation of Sacred Sites, 8 WIDENER L. SYMP. J. 443, 448 (2002).

29. 708 F.2d 735 (D.C. Cir. 1983).

30. Id. at 740 .

31. 638 F.2d 172 (10th Cir. 1980).

32. See id. at 178 . 
necessary. ${ }^{33}$ In Sequoyah, the Sixth Circuit held that the agency's decision to flood the valley did not infringe the Cherokee Indians' free exercise rights, despite the fact that the released waters completely submerged numerous sacred sites. According to the court, the flooding was constitutional because the tribe had failed to offer enough evidence of the centrality or indispensability of that particular valley to Cherokee religious observance. $^{34}$

In these cases, the courts paid little more than lip service to the land management agencies' obligations to consider tribal interests in the lands they had managed. For example, in Wilson, the court concluded that the Forest Service had an obligation only "to avoid unnecessary interference with[] traditional Indian religious practices." ${ }^{35}$ The Wilson court did not make any effort to encourage agency accommodation of Indian interests. Although it held that agencies were obligated to consider tribal interests, the opinion described this obligation as one with "no teeth," implying it would have little effect on how agency decisions were evaluated. ${ }^{36}$

This dismissive attitude toward accommodation changed in Lyng. Although a tribe lost once again, the Court adopted a different conception of land management agencies' obligation to consider and accommodate tribal interests. In foreclosing judicial protection, the Lyng Court shut off one method of protecting sacred sites, but suggested another, more feasible method in its place-agency accommodation.

\section{B. The Supreme Court's Decision in Lyng}

Lyng v. Northwest Indian Cemetery Protective Ass'n effectively ended the possibility of using the First Amendment to force federal agencies to protect Indian sacred sites. ${ }^{37}$ In Lyng, the U.S. Forest Service attempted to complete a logging road through the Six Rivers National Forest in northwestern California, despite the religious use of the area by three Indian tribes. ${ }^{38}$ These tribes challenged the construction of the road, arguing that it violated the Free Exercise Clause of the First Amendment.

The Court held that there was no constitutional violation because the road would not coerce the tribes into violating their religious beliefs: ${ }^{39}$ According to the Court, the case was primarily a dispute over property

33. 620 F.2d 1159 (6th Cir. 1980).

34. Id. at 1164 .

35. Wilson, 708 F.2d at 746 (emphasis added).

36. Id. at 747 .

37. See infra notes 56-59 and accompanying text.

38. Lyng v. Northwest Indian Cemetery Protective Ass'n, 485 U.S. 439, $441-42$ (1988).

39. Id. at 450 . 
rather than one of religious freedom..$^{40}$ As in previous cases, the Court made clear that the power to decide the future of these sites should remain with the government almost exclusively-that the government, in its capacity as a property owner, should have wide latitude to manage its own property as it likes. According to the Court, any other decision would result in a "diminution of the Government's property rights, and the concomitant subsidy of the Indian religion."

Yet at the same time that the Lyng Court upheld " $[t]$ he government's rights to the use of its own land," it also explained that this right "need not and should not discourage [federal agencies] ... from accommodating religious practices like those engaged in by the Indian respondents.",42 Indeed, the Court's opinion evinced a strong support for agency accommodation of Indian sacred sites generally. More specifically, it encouraged accommodations that would "minimize the impact" 43 of the disputed development, and praised the Forest Service for the efforts the agency had already made to reduce this impact-such as picking the route "farthest removed from contemporary spiritual sites" "comprehensive study of the effects that the project would have on the cultural and religious value" of the area. ${ }^{45}$

\section{Why Lyng Was Right: The Problems with Broad Judicial Protection for Sacred Sites}

Although the Lyng Court was sympathetic to Indian concerns regarding their sacred sites, the Court believed that land-use decisions should remain with land management agencies and that giving control over sacred sites to Indian tribes would be an extremely risky proposition. The Court's concern was apparent from its statement that "[h]owever much we might wish that it were otherwise, government simply could not operate if it were required to satisfy every citizen's religious needs and desires. ${ }^{, 46}$ In particular, the Court was worried about the future of sacred site lands and the consequences that would follow if it required the government to manage these lands in

40. Justice Brennan's dissent summarized the majority's position, stating that "the Court believes that Native Americans who request that the Government refrain from destroying their religion effectively seek to exact from the Government de facto beneficial ownership of federal property." Id. at 458 (Brennan, J., dissenting).

41. Id. at 453 (majority opinion).

42. Id. at 454 .

43. Id.

44. Id. (internal quotation marks omitted).

45. Id. The Court described this policy as part of the Forest Service's duty "'to protect and preserve for American Indians their inherent right of freedom to believe, express, and exercise the traditional religions of the American Indian." Id. at 454-55 (quoting the American Indian Religious Freedom Act (AIRFA) of 1978, 42 U.S.C. $§ 1996$ (1982)).

46. Id. at 452 . 
accordance with tribal "religious needs and desires." ${ }^{, 47}$ Such a decision would have effectively granted tribes the exclusive right to control the use of these lands, and the Court was understandably wary of giving them this right. As the Lyng Court concluded, "Whatever rights the Indians may have to the use of the area, ... those rights do not divest the Government of its right to use what is, after all, its land." ${ }^{, 48}$ Although the tribes in Lyng were worried about the overuse of sacred sites land, the Court was just as worried about the potential for underuse.

The Lyng Court correctly recognized that the problem with judicial sacred sites protection is that it is overbroad and would enable tribes to prevent the development of vast swaths of government land. The "tragedy of the commons" explains why a resource will be prone to overuse when multiple owners are each endowed with the privilege to use a given resource and no one has the right to exclude another. Conversely, as Michael Heller demonstrated in The Tragedy of the Anticommons, "[w] there are too many owners holding rights of exclusion, the resource is prone to underuse." exclude others from accessing their sacred sites. By seeking a judicial ruling guaranteeing them a right to veto all proposed uses of sacred site land, they were attempting to solidify this right to exclude. If the Court had granted the tribes this veto right, judicial precedent would have resulted in the granting of similar veto power to hundreds of other tribes, virtually guaranteeing that all Indian sacred sites and surrounding lands would remain unused by anyone but the tribes. ${ }^{50}$ In addition, the veto right sought would not only have been held by the tribe as a group, but would have been available to individual members as well, because the right to free exercise is a personal right. As a result, even if a developer were to secure a tribe's permission to build on a sacred site, dissenting tribal members would still have been able to claim that their individual free exercise rights were being violated.

Although the tribes in Lyng hoped to block all future development, "perpetual non-use of property" is rarely optimal. ${ }^{51}$ According to Heller, "[A]n anticommons regime is a threat to, rather than the epitome of, optimal use." 52 The solution to the tragedy of the anticommons is to eliminate overlapping property rights that create the power to veto potential

47. Id.

48. Id. at 453 .

49. Michael A. Heller, The Tragedy of the Anticommons: Property in the Transition from Marx to Markets, 111 HARV. L. REV. 622, 624 (1998).

50. Heller disputed the previous definition of an anticommons, which required that everyone have the right to exclude. Instead, Heller posited that "non-use can occur even when a few actors have rights of exclusion in a resource that each wants to use." Id. at 669.

51. Id.

52. Id. 
uses of the land..$^{53}$ The Lyng Court's decision to leave control of these lands solely in the hands of the government ensured that federal lands would not be subject to the tragedy of the anticommons. By ruling against the tribes, the Court avoided a situation in which tribes could guarantee the nonuse of significant portions of government land. The Lyng Court realized that the veto power requested by the tribes "could easily require de facto beneficial ownership of some rather spacious tracts of public property," ${ }^{, 54}$ and it accordingly acted to prevent such an occurrence.

The Lyng Court made the right decision because it chose the method of protection that is optimal for society as a whole, even if it is less desirable from the view of individual tribes. Although the opposite ruling might have increased sacred sites protection, it would have come at too great a cost. The existence of other effective methods of protecting sacred sites, as I discuss in Part II, shows that the Court's desire to avoid creating a vast religious servitude on huge expanses of public land was justified. By encouraging agency protection, the Court attempted to increase sacred sites protection, but not to such an extent that it would have generated vast social inefficiencies over broad swaths of government-owned land.

\section{The Criticisms of Lyng}

Scholars harshly criticized the Lyng decision for its perceived insensitivity to Indian religious beliefs and practices. ${ }^{55}$ These critics predicted that the Lyng decision would effectively eliminate the possibility of using the First Amendment to challenge agency decisions regarding the management of sacred sites, and post-Lyng decisions ${ }^{56}$ showed that their

53. Id. at $677-78$.

54. Lyng v. Northwest Indian Cemetery Protective Ass'n, 485 U.S. 439, 453 (1988).

55. See, e.g., Alfred J. Sciarrino, The Rehnquist Court's Free Exercise Collision on the Peyote Road, 23 CUMB. L. REV. 315, 329-30 (1993) (viewing Lyng as marking a "low point" in the Court's modern history of free exercise jurisprudence); id. at 332 (quoting Leonard Haskie, Interim Chairman of the Navajo Tribal Council of Window Rock, Arizona, as characterizing Lyng to be "a further blow to the religious freedom of Native American people"); Ellen Adair Page, Note, The Scope of the Free Exercise Clause: Lyng v. Northwest Indian Cemetery Protective Association, 68 N.C. L. REV. 410, 421 (1990) (concluding that Lyng's restrictive test "reeks of injustice"); J. Brett Pritchard, Note, Conduct and Belief in the Free Exercise Clause: Developments and Deviations in Lyng v. Northwest Indian Cemetery Protective Association, 76 CORNELL L. REV. 268, 292 (1990) (commenting that the Lyng decision "exhibited 'distressing insensitivity" to religious liberties (quoting Sherbert v. Verner, 374 U.S. 398, 41[4] (1963) (Stewart, J., concurring))); S. Alan Ray, Comment, Lyng v. Northwest Indian Cemetery Protective Association: Government Property Rights and the Free Exercise Clause, 16 HASTINGS ConST. L.Q. 483, 511 (1989) (arguing that the Lyng Court ignored past decisions supporting expansive interpretation of the Free Exercise Clause).

56. See, e.g., United States v. Means, 858 F.2d 404, 405 (8th Cir. 1988) (holding that the Forest Service did not violate the First Amendment when it denied a group of Sioux Indians a special use permit that would have allowed them to occupy national forest land that they believed was sacred). 
predictions were correct. ${ }^{57}$ Most tribes and scholars viewed this development as a serious blow to the protection of Indian sacred sites and were unimpressed with the Court's encouragement of agency accommodation. ${ }^{58}$ Many of the same critics strongly agreed with the portion of the Lyng dissent arguing that the majority opinion "effectively bestowed on one party to this conflict [the federal government] the unilateral authority to resolve all future disputes in its favor, subject only to the Court's toothless exhortation to be 'sensitive' to affected religions." 59

Other critics focused on the fact that the Lyng Court's concerns and decision were based on Anglo-American conceptions of property, which rest "on the notion 'that property rights identify a private owner who has title to a set of valued resources with a presumption of full power over those resources." "60 This understanding of property is very different from Indian conceptions of property, which view the "land as utterly incapable of reduction to ownership as property by human beings." commentators objected to the use of Western property values, so different from Indian understandings of property, to determine the future of Indian sacred sites. ${ }^{62}$ Howard Vogel strongly criticized this practice, stating that

57. As Charlton Bonham wrote,

The decision in Lyng effectively marked the end of Native American attempts to employ the Free Exercise Clause to protect Native American religious sites on public lands because it established the demanding "coerced or penalized" standard. Thus, despite the language of the Free Exercise Clause prohibiting governmental interference with religious practices, tribes have been unsuccessful in challenging government actions that harmed tribal sacred sites, which thereby interfered with tribal religious practices.

Bonham, supra note 8, at 165 (footnote omitted).

58. See sources cited supra note 55; see also Rita S. Mandosa, Another Promise Broken, 40 FED. B. NEWS \& J. 109, 111 (1993) ("[T]he greatest damage to Native American religious freedom has come from an April 19, 1988, decision by the United States Supreme Court in Lyng v. Northwest Indian Cemetery Protective Association."); Scott Dalton, Note, Saving Native American Religious Sites: The Haskell Medicine Wheel, KAN. J.L. \& PUB. POL'Y, Winter 1995, at 61, 66 ("The Lyng decision conclusively ended any hope by Native Americans with respect to [the American Indian Religious Freedom Act's] ability to protect their sacred sites when the Court found that AIRFA did not 'create a cause of action or any judicially enforceable individual rights." (quoting Lyng, 485 U.S. at 455)); Johnston, supra note 28, at 450 (stating that the Lyng decision not only ended the possibility of litigation but made any attempts to pass sacred sites legislation more difficult because of the Establishment Clause issue).

59. Lyng, 485 U.S. at 473 (Brennan, J., dissenting), quoted in Howard J. Vogel, The Clash of Stories at Chimney Rock: A Narrative Approach to Cultural Conflict over Native American Sacred Sites on Public Land, 41 SANTA CLARA L. REV. 757, 792 (2001).

60. Angela R. Riley, Indian Remains, Human Rights: Reconsidering Entitlement Under the Native American Graves Protection and Repatriation Act, 34 COLUM. HUM. RTS. L. REV. 49, 83 (2002) (quoting Joseph W. Singer, Property and Social Relations: From Title to Entitlement, in Property and Values: Alternatives to Public and Private OWNERShIP 3, 4 (Charles Geisler \& Gail Daneker eds., 2000)).

61. William Bradford, "With a Very Great Blame on Our Hearts": Reparations, Reconciliation, and an American Indian Plea for Peace with Justice, 27 AM. INDIAN L. REV. 1, 27 (2002-2003).

62. See Riley, supra note 60, at 93 ("Communal, land-based peoples conceive of and interpret ownership in ways that are foreign to, and diminished by, Anglo-American property regimes."); 
"the Anglo-American understanding of land, expressed through a conventional understanding of doctrinal principles of property law, shapes the Court's reading of the facts and adds to the difficulty of seeking a resolution that might heal the conflict." $" 63$

The concern expressed by Vogel and others is justified. The Lyng decision was correct because it avoided an undesirable property situation, but it is also true that under many Indian conceptions of property, such a predicament would never have developed in the first place. ${ }^{64}$ But rather than revealing a problem with judicial sacred sites decisions, this concern about the Anglo-American values that underlay the Lyng decision actually supports the proposition that sacred sites determinations should be made by land management agencies: The Lyng Court's Anglocentric reasoning is merely one in a number of striking illustrations of how agencies are better able to accommodate Indian values and beliefs than the courts or Congress. ${ }^{65}$

\section{E. The Limited Ability of Western Property Law To Protect American Indian Land Rights}

Historically, Western conceptions of property have harmed Indians. The earliest settlers used their understanding of property and ownership to expropriate tribal lands. ${ }^{66}$ In Johnson v. M'Intosh, English common law was used to reach the conclusion that Indian land ownership consisted solely of the right to sell title to the discovering sovereign. ${ }^{67}$ Since then, the Court has repeatedly upheld the imposition of Western property values upon Indian tribes as a means of determining the future of Indian lands. Yet Chief Justice Marshall's opinion in M'Intosh underscores the unsuitability of courts for this task. The M'Intosh opinion demonstrates how courts, as institutions created by the Western legal tradition, cannot escape from

Rebecca Tsosie, Land, Culture, and Community: Reflections on Native Sovereignty and Property in America, 34 IND. L. REV. 1291, 1308 (2001) ("To the extent that courts continue to adjudicate intercultural claims within the Anglo-American property structure, it becomes important to ensure that this structure is not being used to unfairly suppress and disregard Native peoples' interests.").

63. Vogel, supra note 59, at 783.

64. See Carol M. Rose, Possession as the Origin of Property, 52 U. CHI. L. REV. 73, 87 (1985) ("'S]ome Indians professed bewilderment at the concept of owning the land. Indeed they prided themselves on not marking the land but rather on moving lightly through it, living with the land and with its creatures as members of the same family rather than as strangers who visited only to conquer the objects of nature.").

65. See infra Part III.

66. Eric Kades, The Dark Side of Efficiency: Johnson v. M'Intosh and the Expropriation of American Indian Lands, 148 U. PA. L. REV. 1065, 1076 (2000) (noting that "[f]rom the beginning, English government in the New World refused to recognize the Indians as true title holders," that "Virginia's earliest settlers began to articulate a theoretical basis to deny Indian title," and that the Puritans could not accept that hunter-gatherers were "really occupants of their lands").

67. 21 U.S. (8 Wheat.) 543 (1823). 
Western notions of property even when the Court believes those notions produce unjust results. In M'Intosh, Marshall expressed extreme discomfort with the position he was expounding, yet considered it unavoidable. ${ }^{68}$ "Conquest," he wrote, "gives a title which the Courts of the conqueror cannot deny, whatever the private and speculative opinions of individuals may be, respecting the original justice of the claim which has been successfully asserted." 69

The inability of Western law and legal institutions to protect native land rights is similarly demonstrated by the example of the English colonization of the Maori in New Zealand. In New Zealand, English property law was imposed on the Maori in order to facilitate land purchases from them. ${ }^{70}$ Although the English decided to recognize Maori land rights only because such recognition was less costly than a war, once this decision was made, the English truly believed it benefited the Maori. ${ }^{71}$ As Colonial Governor Thomas Gore Browne acknowledged, in "most colonies of the Crown, the natives have been recognised as possessing certain possessory rights over the soil" short of full ownership, while in New Zealand, the Maori had "a right of proprietorship over their lands-not simply a general right of dominion, but a right of proprietorship like the landlords of estates." 72 Yet despite the English colonists' belief that they were treating the Maori fairly, the imposition of Western property law still had detrimental consequences for the Maori people. They "ended up with much less land and very little money," and with the loss of their system of property rights "so too went much of the traditional political structure of the tribes."

Thus, considering how even the benevolent-or at least nonmalicious-imposition of Western notions of property has harmed native peoples, the continued lack of space for Indian property values in the Western legal tradition is understandably disconcerting. However, while Vogel's criticism implicates court decisions, it does not necessarily apply to agency decisionmaking. The courts' use of Western property law to decide

68. See JesSe DUKeminier \& James E. KRIER, Property 12 n.5 (5th ed. 2002) ("The sarcasm and irony seen here and elsewhere in Marshall's opinion suggest his embarrassment with what he had to write, and there is independent evidence that he was sympathetic to the plight of Native Americans.").

69. M'Intosh, 21 U.S. (8 Wheat.) at 588.

70. Stuart Banner, Two Properties, One Land: Law and Space in Nineteenth-Century New Zealand, 24 LAW \& SOC. INQUIRY 807, 830-31 (1999) (stating that the decision to "substitute the English for the Maori system of property ownership" was done to help land "speedily come into the market and become available for purposes of colonisation" (internal quotation marks omitted)).

71. Id. at 822 (remarking that "[t]he recognition of Maori title was a source of some pride to colonial government officials" who believed they had treated the Maori with "unvarying kindness" and that the colonization of New Zealand was achieved according to a "new and humane system" (internal quotation marks omitted)).

72. Id. (internal quotation marks omitted).

73. Id. at 844 . 
cases involving Indian sacred sites may be unfortunate, but it is also unavoidable. These courts were created to implement Anglo-American laws and are bound by judicial precedent. As a result, it is unlikely that even the most sympathetic court would consider it appropriate to discard precedent and incorporate Indian conceptions of property into its sacred sites decisions. As the Court of Federal Claims stated in Hage v. United States, "The Anglo-American case precedent is literally made up of tens of thousands of cases defining property rights over the better part of a millennium. ... [J]udicial decision-making builds historically and logically upon past precedent in narrow cases and controversies rather than current general exigencies or sweeping political mandates.",74

However, the Hage court also explained that this constraint is solely a characteristic of the judicial branch, remarking that " $[t]$ he genius of our Framer[s'] tripartite division of constitutional power is the creation of separated institutions that each best deal with different categories of governmental decisions." 75 Agencies do not face the same restrictions as courts and are consequently much better suited to accommodate Indian conceptions of property and to use them when making their land-use determinations. Unlike courts, agencies are in a position to take competing understandings into account and provide a forum where Indian property values can have an impact on sacred sites decisions. ${ }^{76}$ Agencies are required to consult with Indian tribes when making land-use decisions that will affect them, ${ }^{77}$ and through these consultations, agencies are exposed to alternative conceptions of property. A number of recent examples demonstrate how such exposure has led some agencies to begin acknowledging the validity of Indian viewpoints in ways unlikely to ever occur in a court.

One instance of how such discussions can expose and make agencies more receptive to Indian understandings of the world can be seen in the results of a recent conference between New York state agencies and representatives from New York's Indian tribes. This conference was held to discuss various issues including the preservation of Indian sacred sites. At the conference, the Indian leaders explained a number of misunderstandings that were hurting the two groups' ability to cooperate. "One example that was given was the difference in how the written word is viewed; while

74. 35 Fed. Cl. 147, 151 (1996).

75. Id.

76. See, e.g., Bear Lodge Multiple Use Ass'n v. Babbitt, 175 F.3d 814 (10th Cir. 1999) (discussing the Park Service's creation of a voluntary ban on rock climbing during the month of June, the month when the Cherokee perform their most important religious rituals at the site); see also Brady, supra note 6, at 169 (noting that Deborah Liggett, Superintendent of Devils Tower, "was acutely aware of the significance of land to Native American religious practice"); infra Subsection II.C.1.

77. See infra Section II.A. 
[Anglo-American] society tends to memorialize everything of importance in writing and attaches great importance to the written word, Native culture is based on oral traditions, and the spoken word thus assumes great importance." 78 Such discussions show the potential for agencies to be influenced by exposure to Indian culture and beliefs and to help them avoid many of the problems that have arisen in the past, in this instance problems resulting from the emphasis on oral traditions in Indian culture. ${ }^{79}$ The discussions at the New York conference enabled the two groups to achieve the "first step in establishing a working relationship based on mutual understanding and respect. $" 80$

An even more striking example can be seen in the litigation over alleged unauthorized excavation of an Indian village and burial site in upstate New York. In describing the impact that consultations with the Seneca tribe about their culture and beliefs had on him, Christopher A. Amato, Deputy Chief of the New York State Attorney General's Environmental Protection Bureau, stated that "an understanding of some of the traditional religious beliefs of the Senecas helped us to understand how extremely painful it was for tribal members to learn that the remains of their ancestors were being treated with disrespect." ${ }^{\prime 1} \mathrm{He}$ further added that learning about the tribe's "culture and traditions not only helped frame the litigation but also formed the cornerstone of successful cooperation by enabling the parties to bridge cultural differences." 82 As Amato's statements suggest, making agency officials aware of the differences between American Indian and Western cultures increases the likelihood that agencies will consider these alternative views when working with tribes on matters of tribal concern.

78. Christopher A. Amato, Speaking with One Voice: Elements of Successful State/Tribal Collaboration in Environmental Enforcement, NAT'L ENVTL. ENFORCEMENT J., Sept. 2002, at 3, 12 n. 16.

79. A good example of this conflict can be seen in a 1976 suit brought by the Mashpee Indian tribe under the Nonintercourse Act. The Mashpee claimed that their tribal land had been taken without federal consent, but the district court dismissed the suit because the Mashpee failed to meet the definition of "tribe of Indians" under the Act. Mashpee Tribe v. Town of Mashpee, 447 F. Supp. 940, 950 (D. Mass. 1978), aff d sub nom. Mashpee Tribe v. New Seabury Corp., 592 F.2d 575 (1st Cir. 1979). One of the biggest problems for the Mashpee was the fact that although the tribe claimed to have been continuously self-governing, its claim lacked documentary support. According to one commentator,

Some observers felt the court and jury in Mashpee Tribe heard these oral histories merely as "gaps" in the evidentiary record. "The stories that members of the Mashpee Tribe told were stories that legal ears could not hear. Thus the legal requirements of relevance rendered the Indian storytellers mute and the culture they were portraying invisible."

Stephen D. Osborne, Protecting Tribal Stories: The Perils of Propertization, 28 AM. INDIAN L. REV. 203, 224 n.133 (2003-2004) (quoting Gerald Torres \& Kathryn Milun, Translating Yonnondio by Precedent and Evidence: The Mashpee Indian Case, 1990 DUKE L.J. 625, 649).

80. Amato, supra note 78 , at 5 .

81. Id. at 9.

82. Id. 
Therefore, although Lyng precluded the judicial protection sought by sacred sites advocates, the decision actually made it more likely that land management decisions would be influenced by Indian conceptions of property. The statutory consultation provisions created in response to the lack of judicial protection for sacred sites helped to pave the way for federal land agencies to better understand and accommodate tribal interests in their sacred sites. Since Lyng, agencies like the Park Service, the Forest Service, and the Bureau of Land Management have all increasingly sought ways to protect many of the Indian sacred sites located on federal lands and to accommodate the religious and cultural practices associated with them. ${ }^{83}$

\section{The Effects of Placing SaCRed Sites MANAGEMENT IN AGENCY HANDS}

After Lyng, it became clear that the courts would not mandate protection for Indian sacred sites, and that the majority of such sites would only be protected if federal land management agencies decided that they should be. Although most commentators have been pessimistic about agency protection, largely because "such accommodation is to be had only at the sufferance of the dominant culture, which does not go very far in honoring and respecting the diversity found in Native American culture, the actual results have been quite different than those commonly predicted. ${ }^{85}$ Contrary to the fears expressed by many, agencies are affording real protection to Indian sacred sites. Leaving these decisions in the hands of agencies may actually be the best solution for society in general, even if most tribes would still prefer complete control of these decisions.

While it is unclear how much cases like Lyng directly influenced land management agencies, such judicial decisions affected Congress, and in turn Congress influenced the agencies. Supreme Court cases like Lyng and Employment Division v. Smith ${ }^{86}$ revealed the lack of judicial protections

83. See infra Sections II.B-C.

84. Vogel, supra note 59 , at 789.

85. For examples of such negative predictions, see id. See also Russel L. Barsh, Grounded Visions: Native American Conceptions of Landscapes and Ceremony, 13 ST. THOMAS L. REV. $127,143-53(2000)$ (arguing that the danger faced by Indian sacred sites is that their protection is left too much up to "agency discretion"); Kristen L. Boyles, Note, Saving Sacred Sites: The 1989 Proposed Amendment to the American Indian Religious Freedom Act, 76 CORNELL L. REV. 1117 , 1118 (1991) ("Government agencies frequently make public land management decisions that affect Indian sacred sites located on federal land without considering Indian religion. This lack of cultural sensitivity continually threatens the practice of Indian religion." (footnote omitted)); Luralene D. Tapahe, Comment, After the Religious Freedom Restoration Act: Still No Equal Protection for First American Worshipers, 24 N.M. L. REV. 331, 347 n.72 (1994) (arguing that a stronger sacred sites statute would be the most effective way to prevent "agencies [from] harming sacred sites through development on federal land").

86. 494 U.S. 872 (1990) (holding that a statute forbidding use of peyote, a drug that plays a central role in worship for the Native American Church, did not violate the Free Exercise Clause). 
afforded to Indian religious practices and sacred sites, and convinced Congress of the need to enact greater legislative protections. As a result, a number of statutes were passed or amended with the goal of aiding Indian religious and cultural preservation. In 1992, Congress amended the National Historic Preservation Act (NHPA) of $1966,{ }^{87}$ it did the same in 1988 for the Archeological Resources Protection Act (ARPA) of $1979 .{ }^{88}$ It also passed the Religious Freedom Restoration Act (RFRA) of $1993 .^{89}$ These acts have had a discernible influence on sacred sites protection. However, they are frequently overlooked because, as many critics have pointed out, the legal duties they impose are not particularly onerous. ${ }^{90}$

\section{A. The Enforceability of Statutory Consultation Provisions}

Commentators are making a mistake when they dismiss these statutes simply because they create few legal duties. Regardless of the paucity of statutory requirements and the ease with which they can be satisfied, this legislation has changed agency conceptions of their role with regard to the protection of Indian culture and religion. All of these acts make it clear that Congress expects land management agencies to listen to Indian concerns and try to accommodate Indian religious practices and protect their sacred sites.

The 1992 NHPA amendments, for example, require that the national preservation program be conducted "in partnership with" affected "Indian tribes." In interpreting this provision, agencies have understood their obligations under NHPA as

requir[ing] the agency official to consult with any Indian tribe or Native Hawaiian organization that attaches religious and cultural

87. National Historic Preservation Act Amendments of 1992, Pub. L. No. 102-575, tit. XL, 106 Stat. 4600, 4753-65 (amending 16 U.S.C. $\$ \S 470-470 x-6$ (1988)).

88. Amendments to Archeological Resources Protection Act of 1979, Pub. L. No. 100-588, $\S 1$ (d), 102 Stat. 2983, 2983 (1988) (amending 16 U.S.C. $\S \S 470 \mathrm{aa}-470 \mathrm{~mm}(1988)$ ).

89. Pub. L. No. 103-141, 107 Stat. 1488 (codified in scattered sections of 5 and 42 U.S.C.).

90. See, e.g., Barsh, supra note 85, at 137-38 ("Each of these laws has significant limitations."); Brady, supra note 6, at 173 ("[T]he legislation that has passed has generally been of little practical import.").

91. National Historic Preservation Act Amendments of $1992 \& 4002$ (codified at 16 U.S.C. $\S 470-1(2)(2000)$ ). The amendments also inserted "Indian tribes and Native Hawaiian organizations," $i d$., into the list of groups the Advisory Council on Historic Preservation must "assist ... to expand and accelerate their historic preservation programs and activities," 16 U.S.C. $\S 470-1(6)$. It should be noted, however, that prior to Lyng the 1980 amendments to NHPA announced that "[i]t shall be the policy of the Federal Government" to act "in partnership with the States, local governments, Indian tribes, and private organizations and individuals." National Historic Preservation Act Amendments of 1980, Pub. L. No. 96-515, § 101, 94 Stat. 2987, 2988 (codified as amended at 16 U.S.C. $\S 470-1$ ). The 1980 amendments also required the Advisory Council on Historic Preservation to "inform and educate ... Indian tribes ... as to the Council's authorized activities." Id. $\S 301(\mathrm{~g})(1)$, 94 Stat. at 2999 (codified at 16 U.S.C. $\S 470 \mathrm{j}(\mathrm{a})(7)$ ). 
significance to historic properties that may be affected by an undertaking. This requirement applies regardless of the location of the historic property. Such Indian tribe or Native Hawaiian organization shall be a consulting party. ${ }^{92}$

Furthermore, agencies are required to ensure that such consultation provides an Indian tribe with "reasonable opportunity to identify its concerns about historic properties, advise on the identification and evaluation of historic properties, including those of traditional religious and cultural importance, articulate its views on the undertaking's effects on such properties, and participate in the resolution of adverse effects." ${ }^{.93}$ The regulations further provide that agencies must "make a reasonable and good faith effort to identify Indian tribes" that should be consulted and that "[c]onsultation should commence early in the planning process, in order to identify and discuss relevant preservation issues and resolve concerns about the confidentiality of information on historic properties." 94

\section{The Influence of Legislation on Agency Protection of Sacred Sites}

The 1992 NHPA amendments also had an important effect on agency interpretation of the National Forest Management Act (NFMA) of 1976. ${ }^{95}$ Although no amendments to NFMA forced agencies to reinterpret the Act, the experience of enforcing the 1992 NHPA amendments influenced agency conceptions of their role with regard to the management of Indian sacred sites in other contexts. This voluntary reinterpretation signals a striking change in agency attitudes toward sacred sites.

NFMA itself simply states that the Forest Service must provide for "public participation in the planning for and management of the National Forest System.,"96 Before Lyng, agency regulations required that Indian tribes be notified when tribal lands or treaty rights were expected to be impacted by Forest Service decisions, and the regulations stated that the agency was to "coordinate regional and forest planning with the equivalent and related planning efforts of... Indian tribes."97 However, these regulations only briefly acknowledged the special concerns of Indian tribes. This cursory treatment changed in 2000 , as evidenced by the fact that Indian concerns were given their own section in the National Forest System Land and Resource Management Planning subpart of the Code of Federal

92. 36 C.F.R. $\S 800.2$ (c)(2)(ii) (2004).

93. Id. $\S 800.2(\mathrm{c})(2)(\mathrm{ii})(\mathrm{A})$.

94. $I d$.

95. Pub. L. No. $94-588,90$ Stat. 2949 (codified as amended in scattered sections of 16 U.S.C.).

96. 16 U.S.C. $\S 1602(b)$.

97. 36 C.F.R. $§ 219.7$ (a) (1984) (amended 2000). 
Regulations, entitled "Interaction with American Indian tribes." 98 This section now requires the Forest Service to

consult with and invite American Indian tribes ... to participate in the planning process to assist in:

(1) The early identification of treaty rights, treaty-protected resources, and American Indian tribe trust resources;

(2) The consideration of tribal data and resource knowledge provided by tribal representatives; and

(3) The consideration of tribal concerns and suggestions during decisionmaking. ${ }^{99}$

Like NHPA, ARPA was also amended after Lyng. ARPA had already required consultation with Indian tribes under the terms of the original 1979 Act, ${ }^{100}$ but was amended to include the establishment of "a program to increase public awareness of the significance of the archaeological resources located on... Indian lands and the need to protect such resources." 101

Lastly, RFRA was passed in 1993, in direct response to Smith, ${ }^{102}$ and states that the government can only "substantially burden" the exercise of religion when it has relied on the least restrictive means possible to further a compelling governmental interest. ${ }^{103}$

98. National Forest System Land and Resource Management Planning, 65 Fed. Reg. 67,514, 67,573 (Nov. 9, 2000) (codified at 36 C.F.R. $\$ 219.15$ (2004)).

99. 36 C.F.R. $\$ 219.15(\mathrm{c})$.

100. Archeological Resources Protection Act of 1979, Pub. L. No. 96-95, § 10(a), 93 Stat. 721,727 (codified as amended at 16 U.S.C. $\$ 470 \mathrm{ii}(\mathrm{a})$ ) (requiring agencies to promulgate regulations under the Act only "after consultation with ... Indian tribes"). Since the passage of the Act, the same section of ARPA also has required agencies to consider the provisions of the American Indian Religious Freedom Act of 1978, which mandates that

it shall be the policy of the United States to protect and preserve for American Indians their inherent right of freedom to believe, express, and exercise the traditional religions of the American Indian, Eskimo, Aleut, and Native Hawaiians, including but not limited to access to sites, use and possession of sacred objects, and the freedom to worship through ceremonials and traditional rites.

42 U.S.C. $\$ 1996$.

101. Amendments to Archeological Resources Protection Act of 1979, Pub. L. No. 100-588, $\S 1$ (d), 102 Stat. 2983, 2983 (1988) (codified as amended at 16 U.S.C. 470ii(c)). The amendments also originally required land managers to report to Congress on their efforts, $i d$., but this provision was repealed by the Omnibus Parks and Public Lands Management Act of 1996, Pub. L. No. 104-333, § 814(d)(2)(A), 110 Stat. 4093, 4196 (partially repealing 16 U.S.C. § 470ii(c) (1994)).

102. See Todd L. Tisdale, Culture v. Conservation: Does a Proposed Special Regulation Threaten the Integrity of the National Park System?, 29 B.C. ENVTL. AFF. L. REV. 111, 130 (2001).

103. 42 U.S.C. $\S 2000 \mathrm{bb}-1$ (a) (2000). In City of Boerne v. Flores, the Court held that RFRA as applied to state governments was an unconstitutional extension of federal power. 521 U.S. 507 
NHPA, NFMA, and ARPA all have been interpreted to require agency consultation with affected tribes. Although these statutes and interpretive regulations only mandate discussions with affected tribes and do not force agencies to adopt a tribe's position, they reveal Congress's intention that agencies seriously consider Indian interests in their management decisions. Furthermore, although the courts, as demonstrated in Lyng, will not mandate agency accommodation, they will enforce the statutory consultation provisions as well as agency interpretations of these provisions.

\section{The Importance of the Courts in Agency Protection of Sacred Sites}

In Pueblo of Sandia v. United States, the Tenth Circuit held that the Forest Service's requests for specific information about tribal cultural activities through form letters and at tribal meetings were not reasonable efforts to identify historic properties in the Las Huertas Canyon area as required by NHPA. ${ }^{104}$ According to the court, "[T]he agency did not reasonably pursue the information necessary to evaluate the canyon's eligibility for inclusion in the National Register."105 Because the Sandia court found that the "Forest Service's efforts were neither reasonable nor in good faith," 106 the court reversed the district court's denial of the tribe's request for declarative and injunctive relief and remanded the case. Sandia demonstrates that the "teeth" in these statutes is the requirement that agencies must listen to Indian concerns.

More recently, in Muckleshoot Indian Tribe v. U.S. Forest Service, the Ninth Circuit held not only that consultation with affected tribes is required, but also that the results of such consultation will be enforced. ${ }^{107}$ In Muckleshoot, the court agreed that before initiating the disputed land exchange, the Forest Service had made a "reasonable and good faith effort to identify historic properties" as required by NHPA. ${ }^{108}$ However, the court held that since consultation with the tribe had informed the agency of the significance of "an important tribal ancestral transportation route," and had convinced the agency of the trail's importance, the agency was required to adequately protect the trail from the possible adverse effects of the land

(1997). Subsequent cases, however, have upheld the Act as applied to the federal government. See, e.g., Kikumura v. Hurley, 242 F.3d 950 (10th Cir. 2001).

104. 50 F.3d 856 (10th Cir. 1995).

105. Id. at 860 .

106. Id. at 857 .

107. 177 F.3d 800 (9th Cir. 1999).

108. Id. at 807. 
exchange. ${ }^{109}$ In light of this obligation, the court found the agency's attempts to protect the trail inadequate, enjoined the land exchange, and remanded the case with instructions to the Forest Service "to reconsider whether it [had] located all of the historic properties on the lands it propose[d] to transfer out of federal ownership and what protections should be required." 110 As Muckleshoot shows, judicial enforcement does not end with statutory consultation requirements: Courts will also enforce those regulations that require agencies to act on the information received from such consultations.

One can even see the willingness of courts to enforce agency consultation with tribes in cases decided before statutes like NHPA specifically addressed the issue. In Attakai v. United States, the Navajo Nation brought suit to enjoin the construction of fences and livestock watering facilities on the Hopi Indian Reservation. ${ }^{11}$ The Navajo objected because they had not been consulted about the development, despite the fact that the lands involved were of historic interest to the tribe. ${ }^{12}$ The court agreed and enjoined the Bureau of Indian Affairs from proceeding with the development. The court found that the agency had acted "contrary to the letter and spirit of the regulations," which were promulgated in order to include Indian tribes in decisions regarding historic properties. ${ }^{113}$ The regulations stated that, "[w]hen an undertaking may affect properties of historic significance to an Indian tribe on non-Indian land," that tribe must have "the opportunity to participate." "114 According to the court, "[T]he regulations clearly contemplate[d] participation by Indian tribes regarding lands beyond their own reservations." 115 Consequently, the court held that the Navajo needed to be given the "opportunity to participate as interested persons." "16

In addition to courts, scholars have also acknowledged the importance of consultation between agencies and tribes. Professor Dean Suagee, Director of the First Nations Environmental Law Program at Vermont Law School, characterized consultation provisions as the "the right to have a seat at the table, a chance to persuade the responsible federal official to do the right thing." 117 As Suagee recognized, this right is extremely important. By

109. Id. The court cited the then-current regulations and held that the steps the Forest Service had taken to mitigate the adverse effects of the exchange did not "ensure preservation of the property's significant historic features." Id. at 808.

110. Id. at 815 .

111. 746 F. Supp. 1395 (D. Ariz. 1990).

112. Id. at 1405 .

113. Id. at 1408 .

114. 36 C.F.R. $\S 800.1(\mathrm{c})(2)(\mathrm{iii})(1990)$, quoted in Attakai, 746 F. Supp. at 1408.

115. Attakai, 746 F. Supp. at 1408.

116. Id. at 1409 .

117. Dean B. Suagee, Historical Storytelling and the Growth of Tribal Historic Preservation Programs, 17 NAT. RESOURCES \& ENV'T 86, 88 (2002). 
guaranteeing that tribes will be able to alert agencies to their concerns, these statutes and regulations greatly increase tribes' ability to influence agency decisions.

Although access to agencies does not guarantee that a tribe will be able to influence agency decisions, both agencies and sacred sites supporters frequently acknowledge the importance of such consultations. In his article Federal Consultation with Indian Tribes, Derek Haskew described the competing views of agency consultation and the situations in which consultation is most likely to be effective. ${ }^{118}$ According to Haskew, one view of consultations "is that government recognizes the wisdom of considering the unique perspectives of Native Americans during policy debate, and is making every effort to incorporate those views and interests in federal planning." 119 The other view is that the consultation provisions "may confuse the real consent of Indian communities to federal actions with the procedural illusion of participation, in which Indian consent is never really asked for, and advice is never really heeded." ${ }^{20}$ After a thorough examination of the consultation case law, Haskew concluded that both views are correct in certain circumstances, but that consultation can be expected to work best in situations where courts can legitimately find that "a statutorily created consultation requirement demand[s] something more than a consultation rendered meaningless." "21 Therefore, consultation may be particularly suited for use in the sacred sites context. According to Haskew, sacred sites cases like Sandia show that the combination of a statutory consultation provision and the courts' willingness to enforce it ensures that federal agents will not "ignore the information provided" by tribes when making their land management decisions. ${ }^{122}$

Such judicial willingness to enforce consultation requirements in statutes like NHPA ensures that tribes will have a chance to influence agency decisions. If necessary, a tribe can bring an agency to court for consultation violations. This ability in turn provides an effective check against agency abuse of discretion in general and answers one of the persistent criticisms of agency decisionmaking, which is that Congress

118. Derek C. Haskew, Federal Consultation with Indian Tribes: The Foundation of Enlightened Policy Decisions, or Another Badge of Shame?, 24 AM. INDIAN L. REV. 21 (19992000).

119. Id. at 24 .

120. Id.

121. Id. at 71 .

122. Id. at 72 . But see id. at 74 (stating that consultation provides the "opportunity for Native Americans to express their opinions and desires-with no guarantee that their input will be fully considered or even respected"); see also Robert A. Destro, "By What Right?": The Sources and Limits of Federal Court and Congressional Jurisdiction over Matters "Touching Religion," 29 IND. L. REV. 1, 30 n.135 (1995) (arguing that "neither the states nor the federal government take their respective obligations... very seriously.... especially if such an obligation would interfere with agency discretion"). 
cannot closely monitor every agency decision. As critics rightly note, Congress must rely on external groups to alert it to agency abuses, and "[o]nly when they hear such an alarm will members of Congress turn their attention to the problem." 123 However, cases such as Sandia provide the necessary alarm; they make agency abuses more visible and help alert Congress to these problems.

The consultation provisions in statutes like the NHPA and courts' proven willingness to enforce them have increased the feasibility of informing Congress of agency abuses. In his testimony before Congress, William Day, Chairman of the Culture and Heritage Committee of the United South and Eastern Tribes, Inc., alerted Congress to instances of agency abuse by citing Sandia and similar cases and comparing the facts of those cases to the FCC's current failure to consult with tribal governments before constructing cell phone towers on Indian sacred lands. Day used these cases to demonstrate his belief that the "FCC has been unwilling to live up to its consultation obligations both under the National Historic Preservation Act and the Trust Responsibility to Tribes," and that congressional oversight was needed to curb these abuses. ${ }^{124}$

\section{The Importance of Environmental Groups}

The effectiveness of consultation may also be strengthened by the support of environmental groups for tribal efforts to protect sacred sites. These groups have both the experience and financial resources to enable them to negotiate effectively with agencies and, when necessary, to bring abuses of agency discretion to Congress's attention. For example, in Sandia, the Pueblo of Sandia was joined by the Sandoval Environmental Action Community, Earth First!, the Sandia Mountain Wildlife and Conservation Club, the Sierra Club, and Wildlife Rescue of New Mexico in bringing an action for declaratory and injunctive relief. ${ }^{125}$ The added resources and expertise of groups such as these improve the effectiveness of both tribal consultation with agencies and litigation to enforce consultation provisions. ${ }^{126}$ As a result, the combination of the statutes' consultation

123. Elizabeth Garrett \& Adrian Vermeule, Institutional Design of a Thayerian Congress, 50 DUKE L.J. 1277, 1298 (2001).

124. Telecom Carriers, Tribal Government, and the Siting of Communications Towers: Hearing Before the Senate Comm. on Indian Affairs \& the Communications Subcomm. of the Senate Comm. on Commerce, Sci. \& Transp., 107th Cong. (2002), 2002 WL 20317157 (statement of William Day, Chairman, Culture and Heritage Committee, United South and Eastern Tribes, Inc.).

125. Pueblo of Sandia v. United States, 50 F.3d 856, 856 (10th Cir. 1995).

126. The importance of the aid provided by these environmental groups may also be gleaned from cases in which these groups have argued against tribes, most notably cases concerning traditional tribal uses of endangered animals. In these cases, tribes have frequently lost the right to use these animals even when they were shown to be an integral part of the Indian tribes' religion 
provisions, the courts' willingness to enforce them, and the desire of outside groups to use their resources and expertise to bring abuses to the courts' and Congress's attention has ensured that the right to consultation with agencies is a meaningful one.

\section{Executive Influence on the Protection of Sacred Sites}

In addition, President Clinton shared Congress's concern regarding the protection of Indian culture and sacred sites in the wake of Lyng, and in 1996 he issued Executive Order 13,007, providing that federal agencies “(1) accommodate access to and ceremonial use of Indian sacred sites by Indian religious practitioners and (2) avoid adversely affecting the physical integrity of such sacred sites." ${ }^{127}$ Like the congressional statutes, Executive Order 13,007 may not create onerous legal duties, ${ }^{128}$ but together the statutes and the Order send a clear message to land management agencies that it is their role to accommodate Indian religious practices and protect sacred sites. To the surprise of many, the agencies have listened.

\section{B. The Effectiveness of Consultation Provisions}

The management plan the Park Service created for Rainbow Bridge National Monument provides a good example of the influence of statutory provisions requiring accommodation or consultation. The Park Service issued its management plan for Rainbow Bridge in direct response to Executive Order 13,007 and cited the Order in deciding that Rainbow Bridge was eligible for listing as a national historic place. The agency's eligibility determination was based on criteria very similar to the requirements of Executive Order 13,007. ${ }^{129}$ Furthermore, in Natural Arch \&

and culture. See, e.g., United States v. Dion, 476 U.S. 734 (1986) (finding congressional intent in the Bald and Golden Eagle Protection Act to abrogate Indian treaty rights to hunt eagles); United States v. Hugs, 109 F.3d 1375 (9th Cir. 1997) (holding that burdens on Native American religion imposed by the Bald and Golden Eagle Protection Act were warranted, as the Act served a compelling government interest); United States v. Washington, 520 F.2d 676 (9th Cir. 1975) (upholding tribal whaling rights but with significant limitations); United States v. Billie, $667 \mathrm{~F}$. Supp. 1485, 1492 (S.D. Fla. 1987) (holding that the Endangered Species Act abrogated Indian treaty rights to hunt the endangered Florida panther).

127. 61 Fed. Reg. 26,771, 26,771 (May 29, 1996).

128. See Bonham, supra note 8 , at 172 ("The Order, however, incorporates qualifying language that limits federal land management agency implementation of the objectives to situations where it is 'not clearly inconsistent with essential agency functions' and only 'to the extent practicable.' Executive Order 13,007, therefore, is largely a hortatory and aspirational expression of government policy." (quoting Exec. Order No. 13,007, 61 Fed. Reg. at 26,771)); Tisdale, supra note 102, at 132-33 ("While these statements by the past Administration established a general policy approach for departments and agencies in the Executive Branch, they do not carry the force of law; nor can they override existing laws.").

129. The reviewing court commented on this connection by first describing the 1996 Executive Order and then stating: 
Bridge Society v. Alston, the case that resulted from the controversy over this management plan, the Park Service recognized it had a duty to consider Indian interests in its management plans, regardless of whether or not it actually had a legal obligation to do anything more than hear them. ${ }^{130}$ Legislation such as the 1992 NHPA amendments, regulations such as those implementing NFMA, and Executive Order 13,007 appear to have given the Park Service and other land agencies this new conception of their role. Not only are land agencies becoming more willing to accommodate and protect Indian sacred sites, but the protection they are providing can often be quite effective. In fact, in Bear Lodge Multiple Use Ass' $n$ v. Babbitt, it was only because the Park Service wanted to implement strong protection for Bear Lodge that the agency found itself involved in a lawsuit. ${ }^{131}$

\section{The Legality of Agency Accommodation}

Suits such as Bear Lodge, brought by non-Indian groups who believe that agency accommodation has gone too far, show that the dismissive attitude expressed by many toward agency accommodation has been undeserved. Increasingly, agencies are now under fire because of their willingness to consider Indian interests in the sites they manage. Although Lyng stated that agency accommodation was desirable, as soon as agencies began to accommodate Indian religious practices and protect sacred sites, they were once again faced with First Amendment challenges-this time from those who argued that accommodations represented the impermissible establishment of Indian religion over all others. ${ }^{132}$ Thus far, such suits have proved unsuccessful.

The Establishment Clause of the First Amendment prohibits Congress from making laws "respecting an establishment of religion." However, the Supreme Court has also made it clear that the Establishment Clause does not require " "callous indifference"" to religion. ${ }^{133}$ Although the Constitution prohibits the endorsement of religion, it also "affirmatively mandates accommodation, not merely tolerance, of all religions." 134

Interestingly, in the early 1990s, the National Park Service requested that the Utah State

Historic Preservation Officer ("USHPO") make a determination of eligibility of

Rainbow Bridge for the National Register of Historic Places as a site that has cultural significance based on its traditional and sacred values to Native Americans.

Natural Arch \& Bridge Soc'y v. Alston, 209 F. Supp. 2d 1207, 1226 n.11 (D. Utah 2002), aff'd, No. 02-4099, 2004 WL 569888 (10th Cir. Mar. 23, 2004) (unpublished decision). The court then juxtaposed this decision with the requirements of Executive Order 13,007. Id.

130. Id. at $1225-26$.

131. 175 F.3d 814 (10th Cir. 1999).

132. See Bonham, supra note 8 , at 166 .

133. Lynch v. Donnelly, 465 U.S. 668, 673 (1984) (quoting Zorach v. Clauson, 343 U.S. 306, $314(1952))$.

134. Id. 
The meaning of the Establishment Clause is hotly contested. If the Constitution mandates separation between government and religion, then any accommodation of religion by the government would seem to violate the First Amendment. This is the view of strict separationists. They believe that any governmental accommodation is impermissible, and they base their interpretation of the Establishment Clause on statements of Founding Fathers, such as Thomas Jefferson, who demanded "'the total separation of the anciently meshed powers of church and state." "135

Others interpret the Establishment Clause as requiring accommodation. Accomodationists reconcile the prohibition against religious establishment by differentiating between types of accommodation. For them,

The key difference between legitimate accommodation and impermissible "establishment" is that the former merely removes obstacles to the exercise of a religious conviction adopted for reasons independent of the government's action, while the latter creates an incentive or inducement (in the strong form, a compulsion) to adopt that practice or conviction. ${ }^{136}$

The question for accommodationists is thus whether a given accommodation simply removes obstacles to religious observance or actively encourages such observance.

The Establishment Clause issue is further complicated by the fact that, in other contexts, constitutional provisions have been held to apply differently to Indians because of the special relationship between Indian tribes and the U.S. government. This special relationship gives Congress the authority to develop exemptions and preferences for Indians that might otherwise be unconstitutional. In Morton v. Mancari, the Supreme Court held that "[a]s long as the special treatment can be tied rationally to the fulfillment of Congress' unique obligation toward the Indians, such legislative judgments will not be disturbed." 137 Based on this special relationship, Congress has the authority to provide special protections for Indians that might otherwise violate the Establishment Clause, and thus agency accommodation of Indian religious practices is less likely raise constitutional concerns than the same accommodation for other religious groups.

135. Robert L. Cord \& Howard Ball, The Separation of Church and State: A Debate, 1987 UTAH L. REV. 895, 913 (quoting FAWN M. BRODIE, THOMAS JEFFERSON: AN INTIMATE HISTORY $129(1974))$.

136. Michael W. McConnell, Accommodation of Religion: An Update and a Response to the Critics, 60 GEO. WASH. L. REV. 685, 686 (1992).

137. 417 U.S. 535, 555 (1974) (holding that the hiring policy of the Bureau of Indian Affairs, which gave preference to American Indians, was not a racial preference, but instead was a preference based on membership in a quasi-sovereign group that has a special relationship with the United States). 
In other situations, the federal-tribal relationship has been used successfully to defend statutory exemptions against Establishment Clause challenges. ${ }^{138}$ A number of current federal statutes reflect this intuition. For example, "members of the Native American Church (Indians who use peyote as a sacrament) are exempt from criminal penalties for the possession of peyote." ${ }^{\prime 39}$ Similarly, the Bald and Golden Eagle Protection Act prohibits the possession of eagles or eagle parts, but authorizes the Secretary of the Interior to make an exception for Indian religious purposes under certain circumstances. ${ }^{140}$ Therefore, even if federal accommodation of Indian sacred sites would violate the Establishment Clause under normal circumstances, exceptions for Indians are likely constitutional.

\section{The Conflict over the Management of Bear Lodge/Devils Tower}

Devils Tower National Monument, known to Indians as Bear Lodge, is located in northeastern Wyoming and is a natural phenomenon with great historical and religious significance. President Roosevelt dedicated the tower in 1906 as the first national monument. ${ }^{141}$ Thousands of visitors come each year to view the monument, and some come to climb it, since Devils Tower is considered one of the best rock-climbing locations in the world. ${ }^{142}$ For many Indian tribes, however, Devils Tower is a sacred site. According to religious legend, seven sisters took refuge from a pursuing bear at the tower. There they prayed for the rock's aid, the rock began to grow, and when it reached the sky, the girls turned into the seven stars of the Big Dipper. $^{143}$

These different meanings, one recreational and the other religious, have led to conflict over the management of the tower. Many visitors come hundreds or thousands of miles to climb the tower, but Indian tribes view such climbing as sacrilege and want it to stop. Sensitive to these conflicting concerns, the Park Service attempted to devise a land management plan that could accommodate the varying interests. The Park Service initiated and completed a collaborative process that involved both groups, climbers and tribes. After much time and thought, the Service implemented a plan it hoped would be acceptable to all users of the site. The Park Service's plan called for a voluntary ban on all climbing during the month of June, the

138. See Brent Gunson, Cultural Tug of Wars: An Analysis of the Legal Issues Involving the NPS Proposed Rule To Allow the Taking of Golden Eagles at Wupatki National Monument for Religious Purposes, 22 J. LAND RESOURCES \& ENVTL. L. 399, 416-17 (2002).

139. Lydia T. Grimm, Sacred Lands and the Establishment Clause: Indian Religious Practices on Federal Lands, 12 NAT. RESOURCES \& ENV'T 19, 23 (1997).

140. Bald and Golden Eagle Protection Act $\S 1,16$ U.S.C. $\S$ 668(a) (2000).

141. Bear Lodge Multiple Use Ass'n v. Babbitt, 175 F.3d 814, 819 (10th Cir. 1999).

142. Brady, supra note 6 , at 166.

143. Bonham, supra note 8 , at 158. 
peak month for Indian religious ceremonies at the tower, but permitted climbing throughout the rest of the year. ${ }^{144}$ The plan also prohibited climbers from adding new bolts and fixed pitons, or new routes needing either, and it required camouflaged climbing equipment. ${ }^{145}$

Most of the climbing community accepted the voluntary ban, but a small group of mostly commercial climbing outfits challenged it as a violation of the Establishment Clause. ${ }^{146}$ The district court upheld the voluntary ban ${ }^{147}$ as "a legitimate exercise of the Secretary of the Interior's discretion in managing the Monument." upheld the district court's decision on the ground that the plaintiffs lacked standing. ${ }^{149}$ The key aspect for both courts was the voluntary nature of the ban. ${ }^{150}$

Bear Lodge - and the other cases discussed below-demonstrate that agencies are not only willing to make serious efforts to accommodate Indian interests at sacred sites, but also that these accommodations will be upheld by the courts. Although the ban was voluntary and hence lacked formal enforcement measures, it was highly respected and effective. ${ }^{151}$ Tribal members have strongly approved of it. Charlotte Black Elk, who lives on the Pine Ridge Reservation, indicated that reducing the number of climbers on the tower, especially during the June ceremonies, created "a more suitable atmosphere for prayer," stating that "[b]efore the current June arrangement, we had people looking over the tower at us, (which was) distracting." the Pine Ridge Reservation, said that "the voluntary closure is a good compromise that allows climbers and Native Americans to both use [Bear Lodge]. She said the ceremonies performed in the monument have served to heal Lakota culture, which she said has been overrun by modern American culture." 153

144. See Brady, supra note 6 , at 168.

145. See Bonham, supra note 8 , at 182.

146. Sandra B. Zellmer, Sustaining Geographies of Hope: Cultural Resources on Public Lands, 73 U. COLO. L. REV. 413, 459 (2002). The plaintiffs challenged the law in part because they worried the Park Service would make the ban mandatory if the voluntary ban did not have the desired effect. See Bear Lodge, 175 F.3d at 820.

147. The original plan also banned commercial permits during June, but that aspect was eliminated when it appeared the court would strike it down. See Bonham, supra note 8, at 183-84.

148. Bear Lodge Multiple Use Ass'n v. Babbitt, 2 F. Supp. 2d 1448, 1457 (D. Wyo. 1998), aff'd, 175 F.3d 814.

149. See Bear Lodge, 175 F.3d 814

150. See id. at 821-22; Bear Lodge, 2 F. Supp. 2d at 1455-56.

151. Two years after the voluntary ban was enacted, the number of climbers at Devils Tower during the month of June had decreased from 1294 to 193. Karen J. Coates, Stairway to Heaven; When a Climbing Mecca Is Also a Sacred Site, SIERRA, Nov./Dec. 1996, at 27, 28.

152. Jim Hughes, Devils Tower a Monument to Clash of Cultures; Indians Resent Climbers at Site Shrouded in Myth, DENVER POST, July 5, 1998, at B5 (internal quotation marks omitted).

153. Jim Hughes, Devils Tower Deal Resolves Dispute; Most Climbers Heed Voluntary June Ban, DENVER POST, July 13, 1997, at B3, 1997 WL 6079166. 


\section{Further First Amendment Challenges}

Cases after Bear Lodge have confirmed agency willingness to accommodate tribal concerns, the effectiveness of this accommodation, and courts' readiness to uphold such accommodation. Shortly after the Tenth Circuit's decision in Bear Lodge, similar litigation was brought against the National Park Service in Natural Arch \& Bridge Society v. Alston. ${ }^{154}$ Plaintiffs challenged the Park Service's policy of informing tourists of the sacredness of Rainbow Bridge to local tribes and asking them not to walk under it. Natural Arch \& Bridge Society is especially interesting given the fact that twenty years earlier, in Badoni v. Higginson, ${ }^{155}$ the Park Service had been taken to court because of its callous indifference to the religious significance of Rainbow Bridge. Now it was being sued for providing too much accommodation. Few cases demonstrate a more dramatic change in agency policy. In Natural Arch \& Bridge Society, the plaintiffs argued that the accommodation, which included erecting barriers and posting signs requesting visitors not to walk under the bridge, went too far. Although the case was dismissed for failure to properly join defendants, the court made it clear that had it reached the merits, the accommodation would have been upheld. ${ }^{156}$

Courts have also upheld agency decisions to accommodate Indian sacred sites in situations quite different from these voluntary ban cases. A recent example is Wyoming Sawmills, Inc. v. United States Forest Service, in which a timber company challenged both the adoption of a historic preservation plan for the Medicine Wheel National Historic Landmark by the Forest Service as well as the Forest Service's decision to withdraw a timber sale. ${ }^{157}$ The Medicine Wheel is a prehistoric circular structure of rocks located in Big Horn National Forest in north-central Wyoming, and is considered sacred by numerous Indian tribes. ${ }^{158}$ The Medicine Wheel was designated a national historic landmark in 1969 , but by the late 1980 s the increasing numbers of visitors to the Medicine Wheel convinced the Forest Service that it needed to implement a management plan to better protect the site. ${ }^{159}$

After much consultation with affected parties, the Forest Service adopted a management plan within the framework of its obligations under the National Historic Preservation Act. ${ }^{160}$ The Forest Service's decision was

154. 209 F. Supp. 2d 1207 (D. Utah 2002), aff'd, No. 02-4099, 2004 WL 569888 (10th Cir. Mar. 23, 2004) (unpublished decision).

155. 638 F.2d 172 (10th Cir. 1980).

156. Natural Arch \& Bridge Soc'y, 209 F. Supp. 2d at 1223-26.

157. 179 F. Supp. 2d 1279 (D. Wyo. 2001).

158. Id at 1286 .

159. Id.

160. Id. at 1287 . 
also guided by other laws, such as the Antiquities Act of $1906 ;^{161}$ the Historic Sites, Buildings, and Antiquities Act of $1935 ;{ }^{162}$ the American Indian Religious Freedom Act of $1978 ;{ }^{163}$ ARPA; ${ }^{164}$ and Executive Order $13,007 .{ }^{165}$ In order to comply with its management plan, the Forest Service cancelled a proposed sale of timber because of concerns that the sale would adversely impact the Medicine Wheel site. ${ }^{166}$ The plaintiff in Wyoming Sawmills challenged this decision, alleging that the Forest Service plan "wrongfully promote[d] religion in violation of the establishment clause because promoting the Indian religion was a motivating factor behind [the Forest Service's] decision to enact the [preservation plan]."167

The court disagreed, once again holding that agency accommodation of Indian sacred sites does not violate the Establishment Clause. The plaintiff claimed that the Forest Service regulation prevented it from freely using public areas and that it was offended by the religious symbolism that the regulation advanced. ${ }^{168}$ However, the court found that the plan did not advance any religious symbolism: "Unlike the cases Sawmills cited, the [preservation plan] did not erect any religious symbol anywhere in Big Horn National Forest." "69 In addition, the court questioned whether a "for profit corporation has the capacity to be offended."170 As a result, the court held that Sawmills lacked the "necessary elements of an injury" to establish standing. ${ }^{171}$ The court also found that even if Sawmills's injuries were sufficient for standing, the elements of causation and redressability were

161. 16 U.S.C. $\S \S 431-433$ (2000). The Act authorizes the President "in his discretion, to declare by public proclamation historic landmarks, historic and prehistoric structures, and other objects of historic or scientific interest that are situated upon the lands owned or controlled by the Government of the United States to be national monuments." Id. § 431.

162. Id. $\S \S 461-467$. For a discussion of the Act, see Joe P. Yeager, Federal Preservation Laws: Sites, Structures \& Objects, 8 WIDENER L. SYMP. J. 383 (2002). As Yeager writes,

Although the Historic Sites Act of 1935 provided the Secretary of the Interior with the authority to set up programs for landmark preservation, such as the National Historic Landmark Program, the Act has been attacked for a failure to clarify what procedures govern how a historic property is acquired and designated as a historic landmark. The Historic Sites Act has also been criticized for its failure to integrate historic preservation concerns into federal agency departments, which would arguably provide for better management and enforcement. Nevertheless, the Act remains in force at present, though clearly overshadowed and outdated... [by] the National Historic Preservation Act.

Id. at 389-90 (footnotes omitted).

163. 42 U.S.C. $\$ 1996$.

164. 16 U.S.C. $\$ \S 470 \mathrm{aa}-470 \mathrm{~mm}$.

165. 61 Fed. Reg. 26,771 (May 29, 1996).

166. Wyo. Sawmills, Inc. v. U.S. Forest Serv., 179 F. Supp. 2d 1279, 1289 (D. Wyo. 2001).

167. Id. at 1290.

168. Id. at 1293 ("[The company] claims that it has suffered an injury because it has come in direct contact with unwelcomed religious symbolism endorsed by the United States.").

169. Id. at 1294.

170. Id. at 1295 .

171. Id. at 1294. 
not satisfied. ${ }^{172}$ It made clear that, even if it was the Medicine Wheel itself that offended Sawmills, the court "could not redress that injury because striking down the [preservation plan] would not do away with the Medicine Wheel." ${ }^{173}$ In the two claims for which the court found standing, the court upheld the agency accommodation. Once again, in a situation in which a land agency had made the determination to protect a sacred site and had done so in conformance with what it believed were its regulatory and statutory obligations, the court found the accommodation constitutional. ${ }^{174}$

\section{Why Agency Accommodation Is a Permanent Change}

While these cases demonstrate that agency accommodation has increased in recent years, much of this accommodation occurred under the Clinton Administration, which was highly receptive to sacred sites protection. One of the concerns with agency accommodation for sacred sites, as opposed to statutory or judicial protection, is its potential susceptibility to change across administrations. Many question whether agencies will protect sacred sites under presidents who are less sympathetic to Indian interests. ${ }^{175}$ Although it is still too soon to tell, changes in administration do not appear to have greatly affected the recent trend toward greater sacred sites protection, in part because of the numerous acts requiring agency consultation with affected tribes and the courts' willingness to enforce these requirements. The procedural rights guaranteed in these statutes have been turned into significant protections by tribes and other sacred sites supporters who, in exercising these rights, have changed the way in which land management decisions are made.

The commitment to agency accommodation is demonstrated by the fact that the change in administrations has not dampened efforts to seek out tribal opinions. For example, the Army Corps of Engineers was recently told by the federal Advisory Council on Historic Preservation that it has a duty to protect Indian graves and sacred sites when conducting dam and

172. Id. at $1296-97$.

173. Id. at 1295 .

174. In this case, the Forest Service even consulted with Sawmills and gave it the opportunity to participate in the planning process. For example, the Forest Service gave Sawmills "a draft of the proposed vegetation and timber management sections of the proposed [preservation plan] to review" and asked Sawmills "to participate and attend future information sharing meetings." Id. at 1303-04 (internal quotation marks omitted).

175. See, e.g., Mandosa, supra note 58, at 110 (arguing that "[w]ith the new Republican administration in the 1980 's, a climate more favorable to business interests prevailed, and the government ceased promoting Indian religious freedoms, which often conflicted with economic goals"); see also Sandi B. Zellmer, Indian Lands as Critical Habitat for Indian Nations and Endangered Species: Tribal Survival and Sovereignty Come First, 43 S.D. L. REV. 381, 410 n. 167 (1998) (stating that "it is not uncommon for executive orders [directed at agencies] to be short lived" because of "a subsequent change in administration or administrative policy"). 
river operations. ${ }^{176}$ In response to this advice, the Corps promised to incorporate the obligation to protect Indian sacred sites into its new master manual governing all river operations. Such a decision shows that the Corps considers the protection of sacred sites to be a permanent obligation. The Corps "seem[s] more ready to listen and work with you than ever before," said Tony Provost, environmental director of the Omaha tribe in Nebraska. ${ }^{177}$

Other agencies have also made changes that will have similar impacts well into the future. As tribes have made a greater effort to inform land management agencies about their sacred sites, agencies have become more willing to incorporate this information into their future plans. For instance, as a result of agency identification of sacred sites and consultation with Indian tribes, the Six Rivers National Forest (the location of the proposed road at the core of the Lyng controversy) now has a management plan providing a buffer zone around the sacred site in order to "minimize potential conflict with other uses, and to preserve the ceremonial values of the areas." ${ }^{178}$ Such management plans have an obvious influence on future land management decisions, making it less likely that agency decisions will vary significantly with changes in administration.

However, the greatest indication of permanent change may be the increased willingness of the Bureau of Land Management (BLM), the agency most frequently blamed for indifference toward and destruction of Indian Sacred Sites, ${ }^{179}$ to consider Indian interests in its land management decisions. Two recent decisions illustrate this point.

In February 2001, the BLM granted Anschutz Exploration Corporation a permit to drill an exploratory well in Weatherman Draw, Montana, an area identified by several Indian tribes as having religious significance. At the time the permit was granted, the BLM had determined that the well would cause no significant impact on any Indian sacred sites. In response to this decision, several tribes filed requests for state director review. These requests were granted and oral presentations were made to the agency. Although further review upheld the permit, additional constraints were added on top of its original restrictions, which had already included prohibitions on any activity "during the periods of April 15 to May 16 and September 15 to October 15 when the area is used for Native American

176. Bill Lambrecht, Talks About Sacred Sites Go Well, Say Corps, Tribes; Indians Describe Grief at Looting and Erosion Along Missouri River, ST. LOUIS POST-DISPATCH, Aug. 3, 2003, at $\mathrm{Al}$.

177. Id. (internal quotation marks omitted).

178. Grimm, supra note 139, at 24.

179. See, e.g., Native American Sacred Places: Hearing Before the Senate Comm. on Indian Affairs, 108th Cong. 57 (2003) (statement of Suzan Shown Harjo, President, The Morning Star Institute) (singling out the BLM as having a "record of permitting desecration and destruction of sacred places"). 
religious ceremonies." 180 The agency also added the requirement that "an archeologist ... be on site whenever soil is disturbed, and oil field workers will not be allowed into areas with archeological sites," and the assurance that " $[t]$ he well would be a quarter-mile from the nearest eligible cultural site." 181

Such provisions and restrictions show a continuing awareness and concern for Indian sacred sites. In addition, the Anschutz case also demonstrates the power of consultation. After the permit was upheld, the BLM agreed to further consultations with the affected tribes. A meeting was arranged between the BLM, the tribes, and Anschutz in which "the parties agreed to meet again to work on a negotiated resolution of the matter." 182 This meeting was only the first of many in which Anschutz, the BLM, and the tribes worked together to reach a compromise regarding the future of these lands. In April 2002, after numerous meetings, Anschutz made an unprecedented move and decided to donate its drilling leases to the National Trust for Historic Preservation. ${ }^{183}$ According to Lillian Sparks, a legislative associate with the National Congress of American Indians, this decision showed "the beginning of understanding and the kind of cooperation that can take place between miners and some of our native people." 184 Similarly, Secretary of the Interior Gale Norton described the decision as an example of "the successes we are achieving through the process of consultation, cooperation and communication." 185

The Anschultz decision may not reflect the typical result of consultations between tribes and permit holders, but it does show both the power that consultations can have and the increased willingness on the part of the BLM to encourage these types of negotiations. Although some critics saw the granting of the permit as an indication of a concerning change in administrative policy toward sacred sites, ${ }^{186}$ on closer examination, the BLM's decision actually reflected a continuation of the increased awareness and concern for Indian sacred sites that had begun under the Clinton Administration. ${ }^{187}$

180. Press Release, Bureau of Land Management, Weatherman Draw Oil and Gas Exploration 1 (Dec. 20, 2001), http://www.blm.gov/nhp/efoia/mt/2002/ib/02mtb029_at17.wpd.

181. Id.

182. Id.

183. April Reese, Company Drops Plans To Drill in Montana Valley Held Sacred by Tribes, LAND LETTER, May 2, 2002, at http://www.eenews.net/subscriber/search/swishe-search.cgi (providing a search form to archived materials).

184. Id. (internal quotation marks omitted).

185. Geoffrey Mohan, Mogul Keeps Tribal Site Sacred; Anschutz's Company Rules Out Drilling for Oil in a Montana Canyon Graced with Ancient Indian Art, L.A. TIMES, Apr. 24, 2002, at A10 (internal quotation marks omitted).

186. E.g., Kraker, supra note 12 , at 12 (noting that the permit was granted " 12 days after [George W. Bush] took office").

187. In fact, the Clinton Administration conducted the environmental assessment upon which the permit was granted. See Press Release, supra note 180, at 2. 
A similar example of the BLM's continued willingness to consider Indian concerns in its land management decisions can be seen in the BLM's decision to deny the Dacotah Cement Land Exchange Proposal. Dacotah first approached the BLM with a land exchange proposal in 1997, at which time it was told that such an exchange was possible but that there might be cultural concerns. ${ }^{188}$ A cultural inventory subsequently identified numerous sites of potential cultural significance to tribes in the region. In spite of these findings, in September 2001, Dacotah indicated that it still wished to proceed with the land exchange. Given the potential impact on Indian sacred sites, however, the BLM refused. In fact, the BLM stated that "if the extent of cultural resources had been known earlier, BLM would probably not have entertained this exchange." $" 189$

The BLM's decision to refuse the exchange was based on a concern for the preservation of Indian sacred sites. The BLM held repeated meetings with affected tribes to discuss the potential impact of the exchange. These meetings enabled the tribes to voice their opposition to the exchange and explain the religious and cultural significance of the lands. ${ }^{190}$ As a result, the BLM refused the proposal, even when facing pressure from the Governor of South Dakota to approve the land exchange. ${ }^{191}$

Although the above examples are instances in which agencies have continued to protect sacred sites despite a change in administration, there are exceptions. In situations in which a previous administration has significantly pushed the outer limits of agency accommodation, an incoming administration may consider scaling back some of the most unprecedented decisions, and there have been instances of this trend under the Bush Administration. An obvious example is the Glamis Gold decision. In January 2001, after a six-year permit process, the BLM made an unprecedented choice: ${ }^{192}$ Outgoing Secretary of the Interior Bruce Babbitt

188. Grupo Cementos de Chihuahua (GCC), the successor to the South Dakota state-owned Dacotah Cement, offered to exchange its 3000 -acre Hoffman Ranch to BLM for 2320 acres of public lands with minerals and an additional 3620 acres of federal mineral estate on other GCCowned land. The exchange would have provided GCC with an estimated 200-year limestone supply. Press Release, Bureau of Land Management, Dacotah Cement Land Exchange Proposal 1 (Jan. 3, 2002), http://www.blm.gov/nhp/efoia/mt/2002/ib/02mtb061_at8.wpd.

189. Id.

190. Id.

191. See id.

192. See Christine Knight, Comment, A Regulatory Minefield: Can the Department of Interior Say "No" to a Hardrock Mine?, 73 U. COLO. L. REV. 619, 621 (2002). According to Knight:

[T]he Federal Land Policy and Management Act of 1976 (FLPMA) ... explicitly granted the Department of the Interior the organic authority to manage the federal public lands, including those containing mining claims located under the Hardrock Act. While noting that the rights conveyed by the Hardrock Act remained otherwise intact, FLPMA imposed the following mandate upon the Secretary of the Interior: "In managing the public lands the Secretary shall, by regulation or otherwise, take any action necessary to prevent unnecessary or undue degradation of the lands".... 
denied Glamis a mining permit because of concerns over potential "cultural impacts." 193 This was the first time a mining permit had ever been denied for such reasons. ${ }^{194}$ Ten months later, Secretary Norton rescinded Babbitt's denial and allowed the permitting process to begin all over again. ${ }^{195}$ Norton's decision was based on the Department of the Interior's determination that regulations requiring the consideration of "cultural impacts" were inconsistent with the Federal Land Policy and Management Act (FLPMA) of 1976, which gives the BLM the authority to regulate public lands, ${ }^{196}$ and such regulations were thus an insufficient basis upon which to deny a mine permit. ${ }^{197}$ These events concerning the Glamis mine permit demonstrate the reversals that may occur when a subsequent administration believes an earlier administration has gone too far.

In the Glamis case, it is highly likely that the change in administration did influence the Department of the Interior's decision to reconsider Glamis's permit request. However, Glamis was a unique case. It was an example of an agency bending over backwards to accommodate Indian interests. Secretary Babbitt's decision to deny the mining permit was both controversial and unprecedented. Not only was the mine denied in the final days of the Clinton Administration, but it was also the first time a mining permit had ever been denied based on the interpretation that the " "unnecessary or undue degradation of the lands""198 provision of FLPMA applied to the "cultural ... resource values of the public lands.", 199 This interpretation was quite controversial because "for over one hundred years, the right to mine on public land had been unquestioned." 200

Therefore, although the change to a more conservative administration is likely to reverse some of the most radical instances of agency accommodation, as in Glamis, most instances of agency accommodation do not fall into this category. If an agency decides to accommodate Indian sacred sites under one administration, it appears more likely than not that

Id. (quoting 43 U.S.C. $\$ 1732$ (b) (2000) (emphasis added)). In 2001, the BLM enacted revised mining regulations that imposed even more stringent standards by granting the Department of the Interior the right to deny a mining permit where "substantial, irreparable harm to significant scientific, cultural, or environmental resource values of the public lands" would result, and could not be "effectively mitigated." 43 C.F.R. $\S 3809.5$ (2001), quoted in Knight, supra, at 622-23. It was under this provision that the BLM denied the Glamis mine permit.

193. Kraker, supra note 12, at 14.

194. Id.

195. Id.

196. 43 U.S.C. $\S \S 1701-1785$.

197. See Tom Kenworthy, New Mining Rules Reverse Provisions, USA TODAY, Oct. 26, 2001, at 8A; see also Press Release, Bureau of Land Management, BLM To Retain Key Hardrock Mining Rule Provision (Oct. 25, 2001), http://www.nv.blm.gov/News.Releases/Press_Releases/ fy2002/PR0204.htm.

198. Knight, supra note 192, at 621 (quoting 43 U.S.C. $\S 1732(\mathrm{~b})$ ).

199. Id. at $622-23$ (quoting 43 C.F.R. $\$ 3809.5(2001)$ ).

200. Id. at 623 . 
this accommodation will continue through subsequent administrations as well. As critics rightly point out, agency decisions are easier to reverse than court decisions or legislation, but as discussed in the next Part, this flexibility makes agency protection preferable to First Amendment protection or a comprehensive sacred sites statute.

\section{THE BENEFITS OF AGENCY ACCOMMODATION VERSUS BROADER FORMS OF PROTECTION}

\section{A. The Unique Protection Afforded by Agencies}

Although critics are right when they argue that a Supreme Court decision or a comprehensive sacred sites statute would offer broader protection for sacred sites, they are wrong when they argue that such an approach would be preferable. As demonstrated above, the broad judicial and legislative methods of protection advocated by most sacred sites supporters are not the only ways to protect these sites. Tribes prefer such methods because they are more likely to provide sweeping protection for all sacred sites in all circumstances. Judicial and legislative methods of protection would necessarily have to be extremely broad because the courts and Congress are both ill-equipped to make potentially thousands of detailed, individualized determinations as to whether and how a particular site should be protected. This means that such protections would be grossly overinclusive if made by the courts or Congress, preventing the use of lands that the majority of society would want to be developed. In contrast, such overinclusiveness is not a problem for agencies, which can adopt quite specific protection plans. Furthermore, site-specific protection by agencies, although narrower, is likely to satisfy more people than the type of broad protection that would result from a Supreme Court opinion or congressional statute.

Because agencies are already managing many of these sites, giving agencies the power to make the rules that they will be enforcing increases the likelihood that these rules will be a better fit with the agency, the monument, and all those using the land than would rules resulting from court opinions or broad legislative provisions. In Bear Lodge, the Park Service spent years developing a management plan that took all competing concerns into consideration and attempted to create a solution acceptable to all interested parties. The result was extremely site-specific-much of it concerned climbing and the specific effects of climbing on Devils Towerand would not have been appropriate for most or even many other sacred sites. If individual agencies make the rules that they are going to have to enforce, these rules will fit better with the protected area, and the land agencies will be better equipped to enforce them. 
Another example of how agency-devised regulations are more easily tailored to specific sites than those promulgated by the courts or Congress can be seen in the management plan governing Rainbow Bridge National Monument. At Rainbow Bridge, park rangers enforce the voluntary ban on walking under the monument by informing visitors of the sacredness of the site and explaining why they might not want to walk under it. ${ }^{201}$ Such a regulation tries to accommodate all users of the site, even though it might not be what either group would have chosen on its own. However, this is the type of regulation that could only be devised by an agency intimately familiar with the site it is regulating.

Leaving decisionmaking in the hands of the agencies administering the sites also creates fairer, more balanced decisions. Agencies are likely to be more familiar with the land dispute than either the courts or Congress, and they will consequently have a better sense of the possible compromises that can be reached. For instance, the agency decision regarding Zuni Salt Lake shows how agencies can create an acceptable compromise even when the solution they propose is different from the ones initially requested by the parties. The Zuni Salt Lake and the area around it are sacred to the Zuni and other Pueblo tribes. ${ }^{202}$ In May 2002, the Department of the Interior gave the Salt River Project permission to begin work on a mine in the area that would have required 4000 acre-feet of water per year from local aquifers in order to work. ${ }^{203}$ The Zuni feared this pumping would drain their lake and wanted it stopped. Sensitive to the concerns of both groups, the Department came up with a compromise that allowed the construction of the mine to proceed, but also protected the lake. The Department imposed a number of restrictions on the mining project, including an absolute prohibition on any pumping from the Dakota Aquifer, the aquifer most vital to the lake's survival. ${ }^{204}$ The plan also required the "Salt River Project to consult with Indian tribes to develop cultural awareness programs for mine employees and contractors." 205 This compromise is the type of solution that could only be devised by an agency; it will allow the mine to be built, bringing hundreds of jobs to the area, but it will not destroy the Zuni Salt Lake. ${ }^{206}$

Agency accommodation also creates an alternative to the traditional liability and property rules that courts usually choose between when making land-use determinations. In many of these sacred sites cases, neither a property nor a liability rule would create an acceptable solution to the

201. Bonham, supra note 8, at 190.

202. See Winona Laduke, The Salt Woman and the Coal Mine, SiERrA, Nov./Dec. 2002, at 44,46 .

203. Kraker, supra note 12 , at 13 .

204. Id. at B3.

205. Leslie Linthicum, Zunis Seek Help in Mine Fight, AlbuQUerque J., July 17, 2002,

206. Id. 
problem. For example, in the Zuni Salt Lake case, if the Zuni had been given a property rule they would have simply prohibited the construction of the mine, regardless of the most efficient outcome: Unlike most property use situations, religious sites are less susceptible to bargaining, even if a compromise would benefit both parties. A liability rule requiring the Salt River Project to compensate the tribe for the destruction of the site would be similarly undesirable, given the difficulty of placing monetary value on a sacred site. If the construction of the mine destroyed the Zuni Salt Lake, no amount of money could adequately compensate the Zuni Pueblo for their loss. Accordingly, agency accommodation, which is able to take religious value into account in a way that a strict property- or liability-rule regime cannot, seems ideally suited for these types of land disputes. Agency decisions can create the most efficient outcomes because, in considering the desires of each side, agencies are more likely to leave both parties to the dispute better off than if one side had the unilateral ability to determine the future of sacred site land. Although tribes like the Zuni might find agency accommodation less desirable than protection that would give them complete control over their sacred sites, agency protection, which can accommodate competing interests while still protecting sacred sites, is preferable from the perspective of society as a whole.

Furthermore, the benefit of leaving land-use determinations in agency hands is especially high because sacred sites regulation is rarely a zero-sum game. Again, as the Zuni Salt Lake example demonstrates, lands can often be used in a variety of different ways without foreclosing all other uses. Furthermore, even in instances of irreconcilable incompatibility, such as the flooding that destroyed the Cherokee burial sites in the Tennessee Valley, ${ }^{207}$ it still may be best to leave such decisions in the hands of individual agencies, so that these types of decisions can be made on a case-by-case basis and not as the result of sweeping rules that leave no room for compromise even when compromise is an option.

\section{B. Protection Against.Agency Abuse}

The concerns with agency protection are not unfounded. While agencies have the ability to provide real protection for Indian sacred sites, their only legal obligation is to consult with affected tribes. Observers understandably worry that tribes are overly dependent on agency "good will" for the protection of their sacred sites. ${ }^{208}$ However, the choice to leave

207. See supra text accompanying note 23 .

208. Robert S. Michaelsen, Is the Miner's Canary Silent? Implications of the Supreme Court's Denial of American Indian Free Exercise of Religion Claims, 6 J.L. \& RELIGION 97, 105 (1988) (arguing that "Indian religious practitioners .... are left with no other avenues of recourse 
these decisions in agency hands is not one based on blind faith. If agencies accept their responsibility to protect Indian sacred sites, then their protection is preferable for the reasons discussed above. Furthermore, if agencies fail to adequately protect these sites, Indian sacred sites will not necessarily go without protection: Tribes have other forms of recourse and are not solely dependent on agency goodwill.

In particular, every year for the past two decades Congress has protected at least one individual sacred site. ${ }^{209}$ For instance, Congress designated El Malpais in New Mexico a national monument in 1987. ${ }^{210}$ This area, created by ancient lava flows, has been considered sacred by the Acoma, Hopi, and Zuni tribes for more than 10,000 years. ${ }^{211}$ Similarly, in 1993 Congress passed an Act recognizing the Hawaiian island of Kaho'olawe, which is sacred to Native Hawaiians, as a national cultural treasure, permanently stopped its use as a military training facility, and then returned the island to the state of Hawaii. ${ }^{212}$ In 2000, Congress passed the Timbisha Shoshone Homeland Act, authorizing the purchase of five parcels of land as a reservation for the Timbisha Shoshone tribe, and an additional two parcels that were part of the tribes' ancestral homeland and that have historical, cultural, and spiritual significance for the tribe. ${ }^{213}$ These individual protection statutes are similar to agency protection in that the determinations are made on a case-by-case basis and extend specific protection to individual sites, but also serve as a safety valve for those instances in which agency protections alone may fail. Through its readiness to enact such statutes, Congress has demonstrated that it is willing to protect individual sacred sites. Therefore, if an agency were to deny protection to an Indian sacred site, a tribe would still have the option of seeking congressional protection.

\section{CONCLUSION}

The courts and Congress have left sacred sites protection in the hands of land management agencies, and although many feared this decision would be disastrous, land agencies have actually embraced their role and sought to accommodate Indian religions and protect their sacred sites.

than the good will of governmental administrative agencies"); Lee, supra note 7, at 287 (describing how the protections of the AIRFA are dependant on agency "good will").

209. Indians Urge Cohesive Policy on Sacred Lands, COM. APPEAL, Dec. 14, 2002, at F4.

210. Act of Dec. 31, 1987, Pub. L. No. 100-225, 101 Stat. 1539. at Cl.

211. Joseph Maes, The Lava Tubes of El Malpais, SANTA FE NEW MEXICAN, Jan. 16, 2003,

212. See Department of Defense Appropriations Act, 1994, Pub. L. No. 103-139, §§ 10,00110,004, 107 Stat. 1418, 1480-84 (1993).

213. Pub. L. No. $106-423,114$ Stat. 1875 (2000) (codified at 16 U.S.C. $\S 410$ aaa note $(2000)$ ). 
Furthermore, agency accommodation is actually better for society as a whole than the broader judicial and legislative protections typically advocated by sacred sites supporters. Agency accommodation avoids the disadvantages of broad categorical protection while still serving as a strong method for preserving sacred sites. Although land agencies have had the role of sacred sites protectors thrust upon them, they seem to have turned out to be ideally suited for the job. 